Ricardo da Silva Azevedo

\title{
CLÁUSULA “KNOCK FOR KNOCK” NA INDÚSTRIA PETROLÍFERA SOB A ÓTICA DA LEGISLAÇÃO BRASILEIRA
}

\author{
DEPARTAMENTO DE DIREITO \\ Professor Orientador: Leonardo Teixeira
}




\section{CLÁUSULA “KNOCK FOR KNOCK” NA INDÚSTRIA} PETROLÍFERA SOB A ÓTICA DA LEGISLAÇÃO BRASILEIRA

Trabalho de Conclusão de Curso apresentado como exigência da PósGraduação de Direito dos Contratos da PUC-Rio, como parte dos requisitos parciais para a obtenção do título de Especialista.

Rio de Janeiro, março de 2017

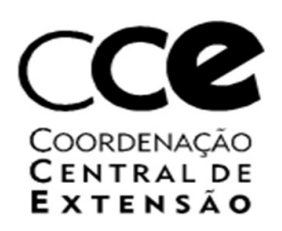




\section{DEDICATÓRIA}

"Dedico esse trabalhoaos meus professores, aos meus pais, ao meu irmão $e$ à minha companheira, presentes e exemplos em todos os momentos." 


\section{AGRADECIMENTO}

“Agradeço a Deus pois é ele que dá forças além dos limites para conseguir as vitórias;

Aos meus pais Ricardo Santos Azevedo e Roseméry Orlandini da Silva Azevedo e ao meu irmão Christiano da Silva Azevedo pelos conselhos, lições de vida, amor e por fazer parte da minha vida em todos os momentos;

A minha esposa Roberta Alvares Ferreira de Souza Azevedo pelo incentivo, compreensão, amor e apoio incondicional.

Agradeço aos meus professores e colegas de turma que independentemente de não ser um advogado, sempre estiveram ao meu lado, transmitindo conhecimentos e experiências, auxiliando no que fosse preciso e me incentivando durante todo o curso;

A TODOS, MINHA ETERNA GRATIDÃO!"

Ricardo da Silva Azevedo 


\section{RESUMO}

A indústria de óleo e gás apesar de estar sofrendo com a redução de recursos, diminuição nas atividades e a contração do valor de sua commodity, ainda é o setor que mais investe no país representando, segundo dados do BNDES, 53\% do capital a ser investido pela indústria brasileira no triênio 20162019.

Baseado nesta informação o presente estudo foi executado com o objetivo de analisar a cláusula "Knock for Knock", largamente utilizada no mercado petrolífero mundial, verificando a sua validade perante a legislação brasileira.

Para esta averiguação, será estudado o instituto da responsabilidade civil e a sua regra geral quanto ao entendimento de que o causador do dano tem que reparar integralmente os danos que causou. Também será analisado a validade da aplicação da cláusula de não indenizar perante o Código Civil de 2002, bem como a aplicação do princípio da autonomia da vontade e o uso de cláusula compromissória nos contratos internacionais da indústria de óleo e gás, com o foco especial no que diz respeito a escolha do foro e lei a ser aplicada em tais contratos pactuados. Além disso, serão exploradas as principais características da cláusula "Knock for Knock" e a razão pela qual os atores da indústria petrolífera utilizam-a.

Desta forma, o presente estudo pretende contribuir para uma análise mais profunda sobre a validade da recepção da cláusula "Knock for Knock" no ordenamento jurídico brasileiro.

Palavras-chave: Cláusula "Knock for Knock". Responsabilidade Civil. Cláusula de Não Indenizar. Cláusula Compromissória. Autonomia da Vontade. Indústria de Óleo e Gás. 


\section{ABSTRACT}

Despite of being suffering a reduction in resources, a decrease in activities and a contraction in the value of its commodity, according to BNDES the oil and gas industry is the sector that most invests in the country, representing $53 \%$ of the capital to be invested in the Brazilian industry in the 2016-2019 triennium.

Based on this information, the present study was made with the purpose of analyzing the "Knock for Knock" clause, which is very used in contracts for world oil market, verifying its validity under the Brazilian law.

For this evaluation it will be studied the institute of Civil Responsibility and its general rule regarding the understanding that the part who causes the damage must indemnify for fully damages caused. It will also analyze the possibility of application the non-indemnity clause in the Brazilian Civil Code, as well as the application of the free will principle and the use of arbitration clause in the oil and gas international contracts with a special focus on the choice of the Forum and law to be applied in this contractual agreements. In addition, we will examine the main features of the "Knock for Knock" clause and the reason why players uses it in the oil industry.

This study has the intention to contribute with a deeper analysis around the validation and the reception of the "Knock for Knock" clause regards the Brazilian law.

Keywords: Knock for Knock Clause. Civil Responsibility. Non-Indemnity Clause. Arbitration Clause. Free Will Principle. Oil and Gas Industry. 


\section{SUMÁRIO}

INTRODUÇÃO

1. A INDÚSTRIA DO PETRÓLEO NO BRASIL......................................14

1.1. História da Atividade Petrolífera no Brasil...................................14

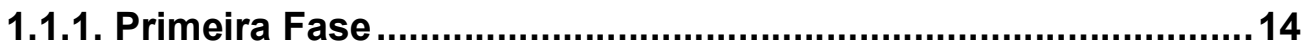

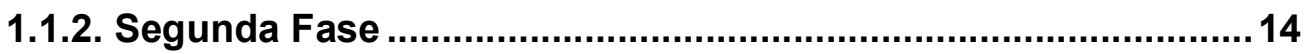

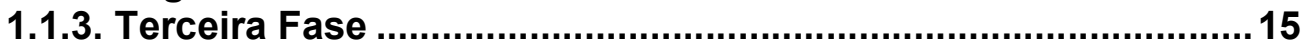

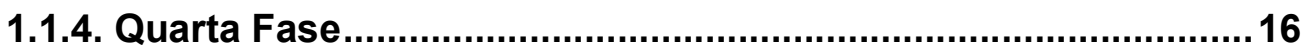

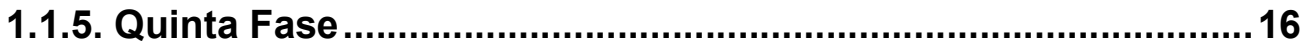

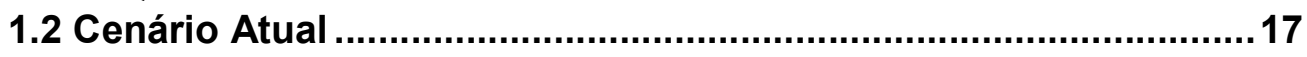

2. PRINCIPAIS CARACTERÍSTICAS DA CLÁUSULA

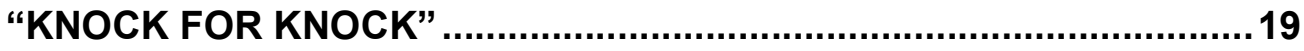

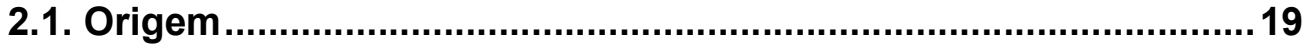

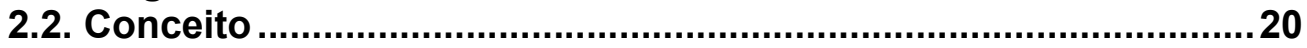

2.3 Exceções dentro do modelo "Knock for Knock" .........................21

3. PRINCIPAIS PROBLEMAS E DIVERGÊNCIAS DA UTILIZAÇÃO DO MODELO "KNOCK FOR KNOCK" COM A CODIFICAÇÃO

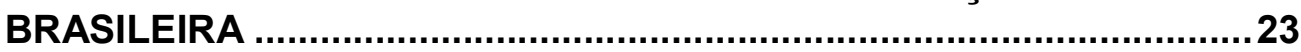

3.1. 0 dever de indenizar na legislação brasileira................................23

3.1.1. O Instituto da Responsabilidade Civil ......................................23

3.1.2. Responsabilidade Subjetiva e Objetiva ....................................25

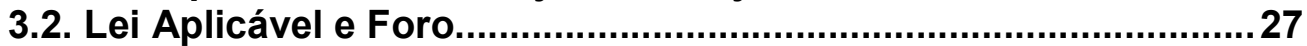

3.3. Utilização da Cláusula Compromissória .......................................29

4. CLÁUSULA DE NÃO INDENIZAR NO DIREITO BRASILEIRO ..........33

4.1. Conceito

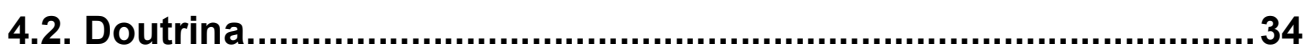

4.3. Autonomia da Vontade ..............................................................36

4.4. Requisitos para Validade da Cláusula de Não Indenizar e Suas

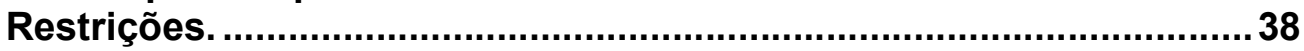

5. DEFESA DA UTILIZAÇÃO DO MODELO “KNOCK FOR KNOCK”...46

5.1. Gerenciamento do Risco e a Cláusula "Knock for Knock" .........46

5.2. Razão de Utilização da Cláusula "Knock for Knock" pela

Indústria Petrolífera 
5.3. Defesa da Utilização da Cláusula "Knock for Knock" perante o Ordenamento Brasileiro

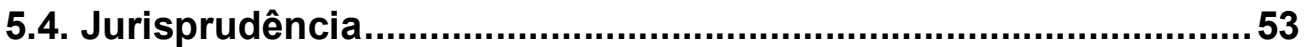

CONCLUSÃO

REFERÊNCIAS BIBLIOGRÁFICAS .................................................58

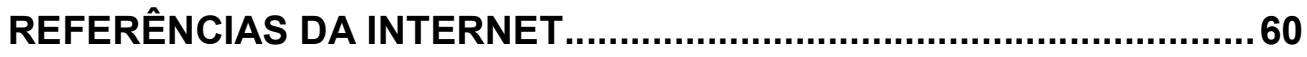




\section{LISTA DE FIGURAS}

Figura 1 - Acidente no Campo de Macondo no Golfo do México Estados Unidos ................................................................................45 


\section{INTRODUÇÃO}

A atividade de exploração e produção de petróleo e gás natural teve seu inicio em 1859 nos Estados Unidos da América com a descoberta do petróleo na cidade de Tittusville, no estado da Pensilvânia, em um poço de apenas vinte e um metros de profundidade, fato que resultou no nascimento dos primeiros contratos de petróleo e gás.

Durante o primeiro século de atividade, apenas os Estados Unidos produziam petróleo. Sua produção era destinada para o consumo próprio e para demanda do mercado internacional. É importante destacar que ao contrário do que ocorre atualmente no Brasil, nos Estados Unidos o subsolo pertence ao proprietário da área e não à União. Assim, tivemos a ocorrência de diversos contratos entre as companhias produtoras de petróleo e gás e os donos dos terrenos onde as jazidas se encontravam. (AMUI, 2011, Nota do Autor p.XI).

A partir da década de 1920, as companhias petrolíferas norte-americanas lançaram-se no mercado mundial, junto com as suas concorrentes recém-criadas na Inglaterra, França e Holanda, buscando novas áreas para explorar e produzir petróleo, passando a partir deste momento a não mais negociar com proprietários rurais, mas sim com governos nacionais (AMUI, 2011, Nota do Autor p.XI).

Os contratos de óleo e gás em sua grande maioria apresentam terminologias em língua inglesa, as quais são conhecidas em todo o mercado de óleo e gás, como por exemplo podemos citar o próprio "Knock for Knock", terminologia motivo deste estudo. Tal ocorrência se dá pela presença acentuada das companhias norte-americanas nos contratos da indústria petrolífera (AMUI, 2011, Nota do Autor p.XII).

Após mais de cento e cinquenta anos de história e desenvolvimento da indústria de óleo e gás, várias práticas e princípios foram empregados nas companhias petrolíferas. No entanto, estas práticas não são possuidoras de princípio legal ou formal, mas são impostas pela tradição de seu uso. Assim, as nações que necessitam explorar e produzir suas jazidas colocam-se em posição de realizar mudanças no seu sistema legal, adequações dos modelos de contrato ou simplesmente não legislam sobre tal material (AMUI, 2011, Nota do Autor p.XII). 
Apesar de existirem vários modelos de contratos e outros documentos jurídicos criados pela Association of International Petroleum Negotiators ${ }^{1}$ (AIPN) e por outras entidades dedicadas a esta matéria, é de suma importância ter um cuidado especial na utilização destes modelos. Os fundamentos jurídicos dos Estados Unidos da América e da Inglaterra, países estes com grande tradição na atividade de exploração e produção de óleo e gás, são divergentes da legislação brasileira, necessitando assim, de um olhar crítico na utilização destes modelos na indústria de petróleo e gás do Brasil. (AMUI, 2011, Nota do Autor p.XII e XIII).

A despeito da indústria de Óleo e Gás no Brasil atualmente estar sofrendo com o baixo preço de sua commodity e com a turbulência que a Petrobras vem passando em função de seu endividamento e das consequências da operação Lava-Jato e suas ramificações, a mesma ainda é o setor que mais investe no país, representando segundo dados do $\mathrm{BNDES}^{2}, 53 \%$ do capital a ser investido pela indústria brasileira no triênio 2016-2019, totalizando gasto de $\mathrm{R} \$ 296$ bilhões.

Neste contexto, junto a estes investimentos surge também a necessidade de elaborar diversos contratos que irão reger as relações de prestação de serviço, locação, leasing, seguro, arrendamento, aquisições, parcerias, trabalho, operações conjuntas, unitização de campos, uso compartilhado de instalações; dentre outros documentos jurídicos que incluem documentos acessórios como protocolos, memorandos, cartas, editais, partilha de produção, acordos de confidencialidade, licenças de patente, carta garantia e assim por diante (AMUI, 2011, p.6).

Em relação aos documentos jurídicos, podemos dividi-los em 7 grupos, são eles:

- Documentos Preliminares;

- Contratos para Exploração e Produção de Hidrocarbonetos;

- Acordo de Operações Conjuntas (JOA);

- Documentos Decorrentes do Contrato de E\&P;

- Documento entre Blocos;

- Contratos de Serviços com Terceiros;

- Documentos Jurídicos Complementares (AMUI, 2011, p.5).

\footnotetext{
${ }^{1}$ Informação retirada do texto Perspectiva de investimento na indústria brasileira (2016-2019) no site do Instituto Brasileiro de Petróleo, Gás e Biocombustíveis, disponível em: http://www.ibp.org.br/observatorio-do-setor/perspectiva-de-investimento-na-industria-brasileira2016-2019/

2 Tradução Livre: Associação Internacional dos Negociadores do Petróleo
} 
O presente estudo se restringirá ao grupo dos contratos de Serviços com Terceiros, dentro do segmento Upstream ${ }^{3}$ e no instituto do Direito Privado, onde o conceito de cláusulas "Knock for Knock" nos contratos de serviço são largamente utilizadas na indústria do petróleo e gás em várias regiões do mundo, tendo como princípio de tornar as responsabilidades e obrigações de indenizar das partes claras e simples sob uma perspectiva de risco e seguro. Neste modelo, cada parte auto segura os riscos relativos a danos a seu pessoal ou à sua propriedade, o que vai em contradição aos princípios básicos do direito civil brasileiro; onde aquele que causar dano a outrem, fica obrigado a reparar a parte prejudicada de forma proporcional ao dano sofrido. Por estas diferenças, muitas vezes são de difícil aceitação os modelos "Knock for Knock" para parte da jurisprudência brasileira, além de ser uma barreira na hora de selar tais contratos.

O trabalho também ficará limitado aos chamados contratos paritários, aqueles onde as partes negociam em igualdade, onde se verifica a negociação acerca dos termos e condições que regem a relação sem a imposição da parte contratual mais forte (Peres, 2009, p.134).

A metodologia da pesquisa utilizada neste trabalho baseou-se em levantamento bibliográfico através de consultas em livros, artigos, teses, páginas eletrônicas de interesse científico, contratos pré-existentes e pelo levantamento documental através de leis, códigos, planos e políticas. O estudo está estruturado em cinco capítulos.

O primeiro capítulo dissertará sobre a história da indústria petrolífera no Brasil, descrevendo sobre o seu início citando a perfuração dos primeiros poços e das primeiras descobertas e abordando a instalação do monopólio no setor durante a era Vargas. Também é apresentado a criação da Petrobras, bem como os seus feitos, a mudança de estratégia concentrando as suas atividades em altomar visando encontrar grandes bacias produtoras, as descobertas dos primeiros campos gigantes, passando pela abertura do mercado com o fim do monopólio da Petrobras durante o governo Fernando Henrique e por fim uma breve análise do cenário atual da indústria no país.

O segundo capítulo abordará as principais características das cláusulas "Knock for Knock" tratando sobre sua origem bem como as exceções de não indenizar dentro do modelo.

\footnotetext{
3 QUINTANS, Luiz Cezar P. Manual de Direito do Petróleo. p.70. Segundo o autor, "upstream é toda a fase de exploração e produção, sendo que o transporte nesta fase somente pode ser considerado se ocorrer antes de qualquer beneficiamento do óleo e gás."
} 
O terceiro capítulo enfoca nos principais problemas e divergências da utilização do modelo "Knock for Knock" com a codificação brasileira, dissertando sobre o dever de indenizar na legislação brasileira, discorrendo sobre o instituto da responsabilidade civil, classificando as responsabilidades subjetivas e objetivas, dissertando sobre a definição de lei aplicável e foro, além da cláusula compromissória.

O quarto capítulo se caracteriza pelo estudo da cláusula de não indenizar no Direito Brasileiro, versando sobre a doutrina, autonomia da vontade e verificando os fundamentos necessários para validar a cláusula de não indenizar, além de defender a sua utilização. Neste capítulo não abordaremos os contratos de direito público e administrativo, além da inversão do ônus da prova, atos de terceiros e força maior (Dias, 2012, p.177).

Por fim, o quinto capitulo se qualifica pela defesa da utilização do modelo "Knock for Knock" na indústria petrolífera levando em consideração o gerenciamento de risco, a razão da utilização da cláusula "Knock for Knock" pela indústria petrolífera, a defesa de sua utilização perante o ordenamento jurídico brasileiro e a jurisprudência nos tribunais sobre o assunto. 


\section{1.}

\section{A INDÚSTRIA DO PETRÓLEO NO BRASIL}

\subsection{História da Atividade Petrolífera no Brasil}

Ao dissertarmos sobre a história da atividade petrolífera brasileiro, a mesma deve ser apresentada em cinco distintas fases.

\subsubsection{Primeira Fase}

A primeira fase nos remete ao Império, onde no ano de 1858, através do decreto $n^{\circ}$ 2266, o então Marquês de Olinda concede ao Sr. José Barros de Pimentel a faculdade de extrair mineral betuminoso com a finalidade de fabricar querosene de iluminação. Este cenário de exploração a ser realizada por livre iniciativa permaneceu até o ano de 1938. Apesar de não haver restrição a capital estrangeiro, a atividade de exploração petrolífera no Brasil não despertou interesse de outros países, uma vez que mercados como a Venezuela, México e Oriente Médio atraíam a maior parte dos investimentos por possuírem impostos e taxas baixas, além de apresentarem um menor custo de exploração. Outro motivo para este desinteresse, se dá pelo fato de o Brasil nesta época não possuir tecnologia e nem recursos financeiros (THOMAS, 2001, p.3)

\subsubsection{Segunda Fase}

A segunda fase tem início com o Decreto de Lei N538 de 1938 onde é criado o Conselho Nacional de Petróleo (CNP) com o objetivo principal de desenvolver a indústria do petróleo e nacionalizar as riquezas do subsolo brasileiro. Esta iniciativa apresentou resultado após 3 anos de existência com a descoberta da primeira jazida comercial do país, situada em Candeiras, Bahia. Até o final de 1939, aproximadamente 80 poços já tinham sido perfurados. Contudo, apesar da criação da CNP, o maior motivo para o crescimento dos investimentos na indústria nacional de petróleo foi a escassez de combustíveis 
ocasionada pela segunda guerra mundial. É importante destacar que até 1953, o proprietário do terreno onde encontrava-se a jazida de petróleo, possuía liberdade de explorá-la ou cede-la por sua espontânea vontade (THOMAS, 2001, p.3).

\subsubsection{Terceira Fase}

A terceira fase se inicia com Getúlio Vargas em 1953 com a política do "Petróleo é Nosso" e a constituição do monopólio da união sobre a pesquisa de jazidas de petróleo e outros hidrocarbonetos, bem com o seu refino, nacional ou estrangeiro e o seu transporte para qualquer origem através da Lei $N^{\circ} 2004 / 53$, que também estipulou a criação da estatal Petrobras, a única autorizada a explorar a atividade petrolífera no país. Nesta fase, a Petrobras comandou as atividades de exploração de petróleo no Brasil, iniciando suas operações na porção onshore $^{4}$, descobrindo os campos de Tabuleiro dos Martins, em Alagoas; o Taquipe, na Bahia; Carmópolis em Sergipe e o campo de Miranga, Bahia. Devido aos dados pessimistas sobre as reservas terrestres, em 1968 migrou suas atividades para porção offshore ${ }^{5}$, onde obteve sua primeira descoberta no mar em Sergipe no campo de Guaricema e em 1974 a primeira descoberta na bacia de Campos no campo de Enchova, tornando esta a principal bacia exploratória do país (THOMAS, 2001, p.3).

Na década de 1980 ocorreram três fatos de grande magnitude na indústria petrolífera brasileira, foram eles: (i) o reconhecimento da existência de petróleo em Mossoró, no Rio Grande do Norte, que viria a ser a terceira maior área produtora do país; (ii) as descobertas dos campos gigantes de Marlim e Albacora em águas profundas; e (iii) a descoberta de petróleo no Amazonas, no Rio Urucu (THOMAS, 2001, p.3 e 4).

Nas décadas subsequentes tivemos outras grandes descobertas como os campos gigantes de Roncador, Barracuda, ambos na Bacia de Campos, além das descobertas na Bacia de Santos que fizeram desta a segunda maior bacia em produção do país. (THOMAS, 2001, p.4).

\footnotetext{
${ }^{4}$ Os serviços onshore são aqueles prestados nos campos localizado em terra.

${ }^{5}$ Os serviços offshore são aqueles prestados em alto mar com plataformas petroleiras e navios
} 


\subsubsection{Quarta Fase}

Através da sanção da lei 9.748/97 após 40 anos de monopólio, a Petrobras deixa de ser a única autorizada a explorar petróleo e hidrocarbonetos no país, permitindo outras empresas, nacionais e estrangeiras competir com a Petrobras nas atividades de exploração, produção, transporte e refino no Brasil, iniciando assim a quarta fase. Durante o governo do presidente Fernando Henrique Cardoso, esta lei modificou o artigo $177 \S 1^{\circ}$ da Constituição da República/88, autorizando a União a contratar outras empresas privadas para a exploração de petróleo no país. Nesta mesma lei temos a criação da Agencia Nacional de Petróleo (ANP) que tem como objetivo regular e fiscalizar a atividade no mercado petrolífero brasileiro. (QUINTANS, 2015, Apresentação p. XXIV).

Com a abertura do mercado para outras empresas além da Petrobras, este ganhou mais atenção, crescendo os interesses jurídicos e de regulação sobre a indústria de óleo e gás.

Apesar da quebra do monopólio, nos seguimentos da indústria midstream ${ }^{6}$ e downstream ${ }^{7}$ as empresas de capital privado tiveram muito pouco ou praticamente nenhum sucesso.

\subsubsection{Quinta Fase}

Com a descoberta de petróleo na chamada camada pré-sal ${ }^{8}$ e com o pressuposto que nesta nova área de exploração o risco da atividade exploratória seria muito baixo, com a presença de reservas gigantescas e grande capacidade de produção, são promulgadas as Leis $N^{\circ} 12.304 / 2010$ e Lei $N^{\circ} 12.351 / 2010$ durante o governo presidente Luís Inácio Lula da Silva. A primeira tem como

\footnotetext{
${ }^{6}$ QUINTANS, Luiz Cezar P. Manual de Direito do Petróleo. p.71. Segundo o autor, "midstream é a fase que se incorpora ao downstream porque basicamente envolve o transporte de óleo bruto do petróleo (oleoduto, transporte ferroviário, barco ou caminhão) ou do gás (por gasoduto e outros mencionados)".

7 QUINTANS, Luiz Cezar P. Manual de Direito do Petróleo. p.73. Segundo o autor, "downstream pode ser entendido como o segmento da comercialização e da distribuição de produtos derivados de petróleo bruto e gás natural, alcançando os consumidores através de produtos petroquímicos, gasolina, óleo diesel, querosene (incluindo de aviação), gás liquefeito de petróleo (GLP), lubrificantes, óleos combustíveis, ceras, asfalto e etc.".

${ }^{8}$ Artigo 2, IV da Lei 12.351/201 dispõe que a área do pré-sal: "região do subsolo formada por um prisma vertical de profundidade indeterminada com superfície poligonal definida pelas coordenadas geográficas de seus vértices estabelecidos no Anexo desta Lei, bem como outras regiões que venham a ser delimitadas em ato do Poder Executivo, de acordo com a evolução do conhecimento geológico. “
} 
objetivo principal a criação da Pré-Sal Petróleo S.A. (PPSA) com o objeto gerir os contratos de partilhas e realizar a gestão dos contratos de comercialização de petróleo e gás natural, advindos da chamada camada do pré-sal e sem a responsabilidade direta e indireta de executar as atividades de exploração, desenvolvimento, produção e comercialização do petróleo e demais hidrocarbonetos. Já a segunda lei dispõe sobre a obrigatoriedade das empresas de capital privado que querem explorar a região do pré-sal se associarem via consórcio com a Petrobras, onde esta deverá possuir a participação mínima de $30 \%$ em todos os projetos relativos a estas áreas.

\subsection{Cenário Atual}

Atualmente, o Brasil possui 29 bacias sedimentares com potencial para a exploração de petróleo e demais hidrocarbonetos dispostos em uma área de 7.175 milhões de $\mathrm{km}^{2}$. No entanto, em apenas uma pequena porcentagem deste montante apresentam-se empresas praticando a atividades de exploração e produção de petróleo.

Decorrente da descoberta de reservas petrolíferas na camada do pré-sal, o país passou por intensos debates sobre as regras a serem aplicadas na exploração das novas reservas e sobre a distribuição dos recursos gerados. Com criação da Lei N 12.351/2010 ocorreu um desestimulo por parte das empresas de capital privado em investir na atividade petrolífera no Brasil, uma vez que exige que a Petrobras seja o operador único nos campos do pré-sal e ainda determina a participação da mesma em no mínimo $30 \%$ no consórcio.

Em meio às discussões sobre a regulação da área do pré-sal, os leilões de áreas para exploração foram interrompidos entre 2008 e 2013, o que também contribuiu para a queda de investimento no setor de óleo e gás do país.

Outro agravante é o baixo poder de investimento que a Petrobras possui no momento, seja este por culpa do baixo valor da commodity no mundo, concomitante com a política do governo anterior de fixar o preço da gasolina para evitar a inflação no país, seja pelos desvios em seu caixa que estão sendo investigados pela operação "Lava Jato" e suas ramificações, o qual causaram um grande prejuízo a Petrobras.

Neste momento, tramita na Câmara dos Deputados projeto de lei, já aprovado pelo Senado, que propõe o fim da obrigatoriedade da participação da Petrobras em participar com pelo menos $30 \%$ dos investimentos em toda a 
exploração da camada do pré-sal. Caso este projeto de lei seja aprovado, estimase que deverá ocorrer um maior interesse das empresas privadas do setor em investir na indústria petrolífera do país. 


\section{2. PRINCIPAIS CARACTERÍSTICAS DA CLÁUSULA “KNOCK FOR KNOCK"}

\subsection{Origem}

A origem da cláusula "Knock for Knock" nos remete ao início do século 20, na indústria dos seguros de automóveis onde quando ocorria um acidente entre dois ou mais veículos, cada seguradora suportaria o custo da reparação do próprio segurado. O princípio deste acordo se baseava no fato de que os encargos administrativos, custos de investigação de todos os incidentes de seus segurados, seria desproporcional à soma dos riscos de todos os seus segurados, onde tais perdas se verificariam ao longo do tempo (LA HAYE, 2014).

Na década de 1960, com o desenvolvimento da exploração e produção de petróleo e gás no Mar do Norte, se vislumbrou a utilização do conceito "Knock for Knock" regulando a responsabilidade no setor petrolífero tendo como premissa de que cada parte responderá pelos danos causados em sua propriedade ou empregados, incluindo subcontratados, independente da culpa. (LA HAYE, 2014).

A partir da década de 1970, este conceito foi absorvido pelo mercado naval e a indústria de óleo e gás e muitas associações com a Baltic and International Maritime Councip (BIMCO) e a Association of International Petroleum Negotiators (AIPN) desenvolveram modelos de contratos com a lógica de que cada parte deveria ser responsável apenas pelos seus empregados e equipamentos, uma vez que a grande maioria de seus contratos eram de longo prazo e de grande complexidade, evitando assim complicados litígios e disputas judiciais, além de tornar o seguro mais simples e barato. (LA HAYE, 2014).

Recentemente a corte inglesa confirmou a validade da cláusula "Knock for Knock" considerando uma forma de alocação de risco e que o mercado auto desenvolveu para levar em conta as características especiais das operações marítimas e da indústria petrolífera. (LA HAYE, 2014).

\footnotetext{
9 Tradução livre: Conselho Báltico e Internacional Marítimo.
} 


\subsection{Conceito}

Embora ainda desconhecida no ordenamento brasileiro, a cláusula "Knock for Knock" é largamente utilizada na indústria do petróleo, principalmente nos contratos de serviço e nos contratos marítimos.

O seu conceito se baseia na alocação de responsabilidade onde cada parte deverá responder apenas pelos danos causados ao seu patrimônio e aos seus empregados, independente se o prejuízo foi causado pela outra parte, ou seja, cada parte assume o risco sobre o seus equipamentos e funcionários.

Logo, caso ocorra uma ação judicial solicitada por algum representante de uma das partes solicitando indenização à outra parte, a primeira deve indenizar a parte solicitada na ação, independentemente da culpa.

Podemos assim afirmar que o modelo "Knock for Knock" cria uma partilha simples do risco, onde cada parte concorda em ser plenamente responsável por quaisquer danos ao seu patrimônio e aos seus empregados, independente da outra parte.

No passado, a prática deste modelo incluía os casos de dolo ${ }^{10}$ ou culpa grave ${ }^{11}$, ficando o causador livre de quaisquer responsabilidades sobre o dano causado à outra parte. No entanto, com o passar do tempo esta cláusula foi modificada e atualmente os contratos não aceitam mais a exclusão do dolo e da culpa grave, sendo nestes casos o causador do prejuízo responsável por reparar a outra parte.

Para melhor compreensão podemos citar o seguinte exemplo: a Empresa Exploradora de Óleo e Gás X contrata Empresa de Serviço de Cimentação Y e firmam contrato que contém a cláusula "Knock for Knock". Um empregado da Empresa $Y$ sofre lesão durante sua jornada de trabalho e resolve acionar a Empresa $X$ na justiça pois acredita que tal acidente ocorreu por culpa da Empresa $X$, além desta possui uma maior liquidez para pagar sua indenização. Desta forma, a Empresa $Y$ assume a responsabilidade por ressarcir quaisquer custos que a empresa $X$ tenha tido neste caso, mesmo que a Empresa $X$ tenha imputabilidade para com a lesão.

\footnotetext{
10 PEREIRA, Caio Mario da Silva. Instituições do Direito Civil - Vol. I. p.441. Segundo o autor, "dolo consiste na prática ou manobras maliciosamente levadas a efeito por uma parte, a fim de conseguir da outra uma emissão de vontade que lhe traga proveito, ou a terceiro. "

11 DIAS, José de Aquiar. Da Responsabilidade Civil. p.110. Segundo o autor, "A culpa grave só poderá ser a ele equiparada quando reveladora de descaso flagrante, de absoluto desprezo pela segurança. "
} 
O modelo "Knock for Knock" foi aderido pois chegou-se a conclusão que as empresas de serviços não seriam capazes de lidar com toda a responsabilidade e o potencial de destruição de todas as instalações das unidades de produção ou de perfuração. Em uma unidade de produção ou perfuração é comum ter diferentes prestadores de serviço no mesmo espaço e com a alocação de risco correta, permite que não ocorra sobreposição de responsabilidades, o que como consequências, dificultaria a determinação das falhas que por ventura viesse a ocorrer.

\subsection{Exceções dentro da cláusula "Knock for Knock"}

O modelo "Knock for Knock" apresenta algumas exceções quanto a questão de não indenizar. Além do dolo e da culpa grave já citados no item acima, está excluído desta relação os casos em que a propriedade de terceiros é danificada ou que empregados de terceiros sejam afetados.

Nestes casos a não ser que o terceiro seja subcontratado de uma das partes e que a mesma também tenha firmado contrato contendo a cláusula "Knock for Knock", caberá ao tribunal designado estabelecer a porcentagem de culpa, baseado na lei vigente do pais.

Outra matéria vedada quanto a distribuição de responsabilidade é o impacto ao meio ambiente. Até antes do acidente do campo de Macondo, no Golfo do México em 2010, onde segundo informações do governo americano vazaram 4 milhões de barris por uma área de $3200 \mathrm{~km}^{2}$, representando o maior acidente ambiental do mercado petrolífero da história, era comum que as partes acordassem que cada parte arcasse com o acidente ambiental causado. No entanto após tal acidente não vemos mais esta divisão, ficando toda a responsabilidade a cargo da empresa operadora, empresa que detêm a autorização da exploração e produção das reservas em uma determinada área delimitada pelo governo.

No Brasil este modelo de compartilhamento de risco quanto ao meio ambiente nunca foi incorporado nos contratos que possuem a cláusula "Knock for Knock', uma vez que a lei brasileira claramente veda a limitação de indenização quanto a questões de ordem pública, o qual dissertaremos com mais profundidade em outro momento deste trabalho.

Outro barreira encontrada para a aceitação de compartilhamento de risco quanto ao meio ambiente, se dá no fato de que para a empresa operadora 
conseguir uma licença ambiental para o desenvolvimento da atividade de exploração e produção, a mesma tem que apresentar um Programa de Emergência Individual (PEI) provando que possui capacidade (equipamentos, barcos, helicópteros e equipes treinadas) de atuar sozinha em caso de um acidente ambiental ocorrido durante a atividade realizada, não fazendo sentido assim o compartilhamento do risco com as empresas de serviço.

Por fim, outra exceção que pode ocorrer nos contratos com a cláusula "Knock for Knock" é a chamada cláusula de "perda de equipamento". A recorrência deste tipo de ressalva é encontrada principalmente nos chamados contratos de poço ${ }^{12}$.

Este contrato é caracterizado pela disponibilização de equipamentos com alta especificação tecnológica por parte das empresas prestadoras de serviço junto com seus operadores para fazerem as análises dos dados enviados pelos equipamentos, onde este equipamento é colocado dentro do poço perfurado pela empresa contratante. Durante esta operação de decida da aparelhagem, pode ocorrer a perda do equipamento dentro do poço e para recuperá-lo deve-se realizar um procedimento chamado pescaria ${ }^{13}$.

Ocorre que a contratante pode não conseguir realizar a pescaria ou não querer realizar tal procedimento, pois a cada dia que a plataforma de perfuração fica parada o prejuízo causado é enorme. Assim, para que a empresa prestadora de serviço não fique lesada, é inserida está cláusula no contrato, já limitando o valor do bem e obrigando a contratante indenizar a outra parte.

Apesar do equipamento da empresa de serviço não estar na responsabilidade da contratante, neste caso aplica-se a faculdade do dolo.

\footnotetext{
12 Amui, Sandoval Petróleo e Gás Natural para Advogados e Negociadores. p. 126. Segundo o autor, constituem tipicamente os contratos de poço as atividades de: Perfuração de Poços, incluindo afretamento do equipamento e prestação de serviço; Perfilagem de Poços; Cimentação de Poços; e a Completação de Poços. Vale lembrar que dentro destas atividades existem centenas de menores contratos e específicos que fazem parte deste macro serviços.

13 Thomas, José Eduardo, Fundamentos de Engenharia de Petróleo. p. 104. Segundo o autor, "pescaria é o termo utilizado na indústria do petróleo para designar atividade de retirada de qualquer objeto estranho que tenha caído, partido ou ficado preso no poço. Prisão ou ruptura da coluna de perfuração, ruptura de broca ou queda de seus cones, acessórios de perfuração ou de equipamento do poço são casos típicos que necessitam da atividade de pescaria".
} 


\section{3.}

\section{PRINCIPAIS PROBLEMAS E DIVERGÊNCIAS DA UTILIZAÇÃO DA CLÁUSULA “KNOCK FOR KNOCK” COM A CODIFICAÇÃO BRASILEIRA}

\subsection{O dever de indenizar na Legislação Brasileira}

\subsubsection{O Instituto da Responsabilidade Civil}

$\mathrm{Na}$ conjuntura do Instituto da Responsabilidade Civil na legislação brasileira, inicialmente devemos recordar a distinção feita pela doutrina acerca dos deveres jurídicos originários e os deveres jurídicos sucessivos. O primeiro versa sobre os deveres decorrentes da vontade humana ou lei em sentido estrito, já o segundo versa sobre os deveres derivados da violação culposa do dever jurídico originário (Dantas, 1978, p. 21).

Assim, no tocante ao dever jurídico originário devemos lembrar a relação contratual pactuada com os seus respectivos deveres gerados expressados uni ou bilateralmente pelas partes, observando o dever de não prejudicar terceiros e respeitando os direitos da personalidade e da propriedade alheia. Já no caso do dever judiciário sucessivo, o mesmo tem como fonte reparar o dano ocorrido pela transgressão de obrigação contratualmente pactuada ou legal (Avelar, 2012, p.20).

Em relação ao inadimplemento do contrato, podemos subdividi-lo em três categorias, são elas: o cumprimento defeituoso; inadimplemento relativo; e o inadimplemento absoluto.

O cumprimento defeituoso ocorre quando o contrato foi cumprido, mas não da forma exata que tinha sido pactuada (Peres, 2009, p. 38). Por exemplo podemos citar um contrato de buffet onde foi exigido que todos os garçons estivessem de smoking branco, e na hora da execução do serviço todos apareceram vestidos de preto. Neste momento podemos afirmar que ouve um cumprimento defeituoso do contrato. É comum também para alguns doutrinadores 
enxergar este cumprimento defeituoso como a figura da Violação Positiva do Contrato.

Um outro exemplo seria a contratação de um serviço de comunicação via satélite contratada pelo dono de uma plataforma exigindo que a comunicação tivesse velocidade de $10 \mathrm{mb}$, no entanto a empresa de comunicação só entregou $7 \mathrm{mb}$; neste caso podemos considerar que ouve uma Violação Positiva do Contrato, uma vez que há um serviço de comunicação em funcionamento, porém a empresa responsável pelo serviço não entregou a velocidade pactuada.

Nos casos de Violação Positiva do Contrato a lei protege a parte que obteve o dano através do art. 475 do CC que versa "A parte lesada pelo inadimplemento pode pedir a resolução do contrato, se não preferir exigir-lhe o cumprimento, cabendo, em qualquer dos casos, indenização por perdas e danos".

É importante destacar os critérios que devem ser preenchidos para ser aplicado o artigo supracitado. São eles:

(i) Extensão da inexecução;

(ii) A importância da obrigação violada;

(iii) Valor da obrigação não cumprida;

(iv) Interesse do credor e a utilidade da prestação cumprida de forma defeituosa.

Já o inadimplemento relativo ocorre nos casos que o devedor já cumpriu parte essencial da obrigação assumida. Por exemplo, um decorador de festa contrata junto a uma floricultura 100 flores em vasos de cerâmica para um evento para serem entregues em uma determinada manhã de sábado, no entanto na hora acertada, a floricultura entrega 80 flores em vasos de cerâmica e 20 flores em vasos de plástico. Ou seja, de $100 \%$ do contrato acordado, o devedor cumpriu $80 \%$, não podendo assim ser considerado um inadimplemento absoluto.

Outro exemplo seria a contratação de um serviço de transporte aéreo pelo dono de uma plataforma para realizar o embarque de seu pessoal. Fica acordado entre as partes que a empresa aérea deveria realizar 10 voos em um determinado dia, no entanto por uma falha mecânica a mesma só realizou 9 voos. Visto que a empresa aérea realizou $90 \%$ do seu escopo, podemos considerar que houve um inadimplemento relativo da obrigação. Nestes casos fica vedada a resolução do contrato, no entanto o direito de obter o restante do crédito persiste, podendo ajuizar ação de cobrança para tanto. 
Por fim, temos o inadimplemento absoluto, como o próprio nome diz, o devedor não cumpriu o contrato (Peres, 2009, p.33). Como exemplo podemos citar uma noiva que comprou um vestido para usar no casamento, no entanto o mesmo só chegou no dia seguinte, perdendo assim o uso de sua finalidade, não tendo mais razão de manter o contrato, logo podemos considerar que houve um adimplemento absoluto do contrato.

Outro exemplo seria a contratação por parte de uma empresa operadora de uma embarcação para participar de um simulado de resposta a emergência solicitado pelo IBAMA e no dia a mesma apresenta um problema em seu motor e não comparece, novamente neste caso perde-se finalidade de sua contratação.

Nestes casos, influenciada pelo princípio da boa-fé, poderá o credor quando perceber que o devedor não irá cumprir com sua parte no contrato, permitindo que o mesmo atue de forma a não agravar seus danos, devendo invocar a quebra do vínculo contratual, amparado pelo Enunciado $\mathrm{N}^{\circ} 169$ da III Jornada de Direito Civil o qual versa que "o princípio da boa-fé objetiva deve levar o credor a evitar o agravamento do próprio prejuízo”.

\subsubsection{Responsabilidade Subjetiva e Objetiva}

De acordo com a doutrina, podemos considerar que a responsabilidade civil pode ser dividida em responsabilidade subjetiva e objetiva.

A responsabilidade subjetiva foi definida pelo legislador no Código Civil de 1916, através de seu artigo 159 como sendo "a obrigação de reparar o dano imposta a todo aquele que, por ação ou omissão voluntária, negligência ou imprudência, violar o direito de causar prejuízo a outrem".

Já no Código Civil de 2002 em sua interpretação, avoca ato ilícito a violação do direito ou o dano causado (Pereira, 2017, p.553). Ou seja, advém da existência de dolo ou culpa pela parte causadora da lesão. Logo o dever de indenizar ou de exigir indenização se prende ao fato de comprovar culpa ou dolo na ação que causou o dano.

Esta ideia é positivada no Código Civil em seu artigo 186, o qual versa "aquele que, por ação ou omissão voluntária, negligência ou imprudência, violar direito e causar dano a outrem, comete ato ilícito". No entanto, o parágrafo único do artigo 927 do Código Civil, nos remete a responsabilidade objetiva, a qual possui em seu princípio que independente da culpa do causador da lesão, apenas pelo estabelecimento dos nexos de casualidade, o mesmo fica obrigado a reparar 
a parte lesada (Avelar, 2012, p. 22). Este artigo versa que "aquele que por ato ilícito (art. $186^{\circ}$ e art. $187^{\circ}$ ), causar dano a outrem, fica obrigado a repará-lo" e em seu parágrafo único descreve "haverá obrigação de reparar o dano independente de culpa, nos casos específicos em lei, ou quando a atividade normalmente desenvolvida pelo autor do dano implicar. Por sua natureza, risco para os defeitos de outrem".

Como podemos observar, apesar do novo código ter retirado da cláusula geral do artigo 186 a consequência de reparo ao dado, o mesmo foi incluído no artigo 927 do Código Civil permanente do Título da Responsabilidade Civil (Pereira, 2017, p.554). Deste juízo, são retiradas três condições basilares. São elas:

i) Verificação da conduta antijurídica, ou seja, conduta diversa a direito, por comissão ou omissão, não precisando questionar se ocorreu ou não o propósito de fazer mal;

ii) Presença de um dano, lesão a um em jurídico de ordem material ou imaterial, de natureza patrimonial ou não patrimonial;

iii) Existência de nexo de casualidade, verificando de o dano provém de conduta antijurídica, onde a não verificação dos modos contrário a direito não teria ocorrido a violação ao bem jurídico (Pereira, 2017, p.554).

Em relação a reparação do dano moral, este encontra guarida no o art. $5^{\circ}$, V e X da Constituição Federal de 1988 e no artigo 168 do Código Civil (Pereira, 2017, p.554).

Quanto ao dano a terceiros, este provém da existência de nexo de causalidade a respeito do comportamento do agente e do dano, ocorrendo assim a responsabilidade por fato próprio. Uma vez que a relação causal atinge terceiros, o responsável deverá reparar o mal, devido ao vínculo jurídico especial chamado responsabilidade civil por fato de terceiros (Pereira, 2017, p.554);

Apesar de não ser objeto de nosso estudo, a responsabilidade positiva também é positivada no Código de Defesa do Consumidor nos artigos 12, 13 e 14 , onde o consumidor necessita de comprovação de culpa ou dolo ou no caso de produto, vício, para que o vendedor seja obrigado a reparar. Neste caso deve o consumidor apenas apresentar o nexo de casualidade.

Independente da responsabilidade subjetiva e objetiva coexistirem no Código Civil, a prevalência deste último ao longo da evolução da matéria no nosso ordenamento civil é marcante. A doutrina tem prezado pela tese da 
responsabilidade pelo risco, afirmando que para que ocorra a reparação do dano, é necessária apenas a apresentação do nexo causal. Ou seja, aquele que cria atividade, cria um risco e deve suportar o prejuízo que sua conduta acarreta, ainda porque essa atividade de risco lhe proporciona um benefício (Venosa, 2002, p.36).

Assim afirmamos que a responsabilidade civil no nosso código tem ideia de que todo risco deve ser garantido, logo acabando com a tese de que a obrigação da reparação do dano depende apenas de culpa, passando a se basear no risco, ante a dificuldade de obtenção da sua prova pelo lesado. (Alonso, 2000, p.12).

Conforme descrito no parágrafo anterior, a lógica principal do código civil brasileiro se baseia na responsabilidade civil objetiva, isto é, não é necessária a culpa ou dolo para que uma parte tenha que indenizar a outra que sofreu o dano. Necessita apenas do nexo de casualidade entre o fato gerador e o dano causado.

Logo o principio da responsabilidade civil do Código Civil de 2002 é amparado pelo dever de reparação, onde a parte que é responsável ou não pelo fato próprio é forçada a restabelecer o equilíbrio rompido, reparando a vítima o que esta efetivamente perdeu ou o chamado lucro cessante, conforme artigo 402 do Código Civil de 2002 o qual versa "salvo as exceções expressamente previstas em lei, as perdas e danos devidas ao credor abrangem, além do que ele efetivamente perdeu, o que razoavelmente deixou de lucrar." (Pereira, 2017, p. 555).

Posto que no modelo jurisdicional brasileiro as indenizações são regidas pelo Código Civil, podemos afirmar que tal entendimento vai contra ao princípio básico do modelo "Knock for Knock" que apenas considera os casos de dolo ou culpa grave como fonte para se exigir indenização.

\subsection{Lei aplicável e Foro}

A grande maioria dos contratos celebrados na indústria do petróleo são aqueles chamados internacionais, isso porque o Brasil dispõe de uma quantidade

muito limitada de empresas possuidoras de alta tecnologia para suportar o mercado de petróleo e gás, sendo que em alguns serviços específicos, não possui qualquer empresa que possa suportar o mercado de óleo e gás brasileiro, sendo assim necessário recorrer a empresas estrangeira e multinacionais.

Neste cenário, a maioria dos contratos tem sua elaboração no exterior, baseados em legislação estrangeira. Assim, apesar de os serviços serem 
realizados no Brasil e pagos com moeda brasileira e mesmo em alguns casos que o contrato segue conforme as leis brasileiras, tais contratos apresentam diversos elementos que vinculam mais do que um sistema jurídico, além de apresentarem ao menos um agente estrangeiro, sendo considerados assim como Contratos Internacionais.

De acordo com a legislação brasileira, aplicamos em nosso regramento o princípio do nexo de casualidade ou a conexão para determinarmos o foro e a lei aplicável nos contratos privados.

Assim, a determinação da lei aplicável ao contrato, se dará pelo caput. do artigo 9 da Lei de Introdução ao Direito Brasileiro (Decreto-Lei 4657/42) que possui o seguinte texto "para qualificar e reger as obrigações, aplicar-se-á a lei do país em que se constituírem", regendo assim os contratos firmados entre presentes. Para os contratos firmados entre ausentes, devemos considerar o segundo parágrafo no artigo 9 do Decreto-lei 4657/92, o qual versa " A obrigação resultante do contrato reputa-se constituída no lugar em que residir o proponente".

No entanto existem restrições quanto a aplicação do direito estrangeiro, conforme podemos constatar pelo artigo 7 do Decreto-lei 4657/92 que veda a sua aplicação nos casos de ordem pública, bons costumes e soberania nacional, contudo a jurisprudência em relação a este assunto ainda não é sólida.

Em relação ao foro é importante evidenciar que antes da introdução do Novo Código Processual Civil de 2015 havia uma grande insegurança jurídica quanto a esta matéria. Esta era resultante de decisões recentes do Superior Tribunal de Justiça nos casos em que mesmo pactuada a decisão por foro estrangeiro, tal medida não afastava a competência da autoridade brasileira nas situações em que a obrigação era cumprida em território nacional e quando a ação se originava em fato ocorrido no Brasil, ou até mesmo nas situações em que o réu estivesse domiciliado no Brasil, independente de sua nacionalidade seguindo o que versava a letra do artigo 88 do antigo Código Processual Civil/1973 e seus respectivos incisos, indo em posição contrária a jurisprudência consolidada pela Súmula 335 do Superior Tribunal Federal, a qual discorre que "É válida a cláusula de eleição do foro para os processos oriundos do contrato."

Todavia, com a introdução do Novo Código Processual/2015 este assunto foi pacificado reconhecido através do seu artigo 25 onde se afirma que não compete à autoridade judiciária brasileira o processamento e o julgamento da ação quando houver cláusula de eleição de foro exclusivo estrangeiro em contrato internacional, arguida pelo réu na contestação. Entretanto, tal artigo em seu primeiro parágrafo ainda coloca sob competência da autoridade brasileira as 
ações relativas a imóveis situados no Brasil (Art. 23,I, NCPC/15), matéria de sucessão hereditária (Art. 23,II, NCPC/15) e em caso de partilhas de bens situados no Brasil (Art. 23,III, NCPC/15).

Já em seu segundo parágrafo o legislador veda a eleição abusiva de foro, através da remissão do quarto parágrafo do artigo 63 no Novo Código Processual Civil/2015. Em verdade esta hipótese não deve ser considerada em contratos paritários, onde as partes pactuam livremente as regras que regem os seus acordos.

Apesar da Organização dos Estados Americanos (OEA), organização a qual o Brasil faz parte, já ter admitido em Convenção Interamericana sobre Direito Aplicável aos Contratos Internacionais realizada em 1994 a possibilidade de as partes escolherem livremente o direito aplicável que regerão as suas relações, conforme descrito no parágrafo acima, apenas com a introdução do Novo Código Processual Civil de 2015 no sistema legislativo pátrio, o Brasil passou a aceitar tal autonomia de vontade.

\subsection{Utilização da Cláusula Compromissória}

Posto que a lei de introdução do código civil não permitiu que o instituto do direito privado elegesse a sua própria vontade a escolha do foro e da lei

aplicável, tal instituto conseguiu guarida de sua vontade com promulgação da Lei da Arbitragem (Lei 9307/96). Com esta lei, passou-se a permitir que nos contratos de direito privado as partes pudessem exercer a expressão de suas vontades. Este benefício concedido por força do Artigo 2, parágrafo segundo da referida lei, outorgou as partes o poder de convencionar que as arbitragens sejam realizadas com base nos princípios gerais de direito, nos usos e costumes e nas regras internacionais de comércio. Logo para que as partes possam usufruir desta liberdade, as mesmas devem pactuar Cláusula Compromissória em seus contratos.

De acordo com o artigo 4, parágrafo I da Lei da Arbitragem, "A cláusula compromissória deve ser estipulada por escrito, podendo estar inserta no próprio contrato ou em documento apartado que a ele se refira".

No que se refere respeito a contrato de adesão, o parágrafo II do mesmo artigo, versa que "a cláusula compromissória só terá eficácia se o aderente tomar a iniciativa de instituir a arbitragem ou concordar, expressamente, com a sua instituição ...", está proteção se dá pelo fato de que nestes casos deve se 
considerar que em sua grande maioria que uma das partes é hipossuficiente, ou seja, apresenta falta de equivalência material e restrição a autonomia da vontade.

De acordo com a súmula 485 do Superior Tribunal de Justiça, "A Lei de Arbitragem aplica-se aos contratos que contenham cláusula arbitral, ainda que celebrados antes da sua edição.".

Outro fato importante a ser considerado é a exclusão da jurisdição estatal na resolução do mérito que o Novo Código Processual Civil de 2015 (NCPC/2015) trouxe. De acordo com o seu artigo 485, inciso VII, “o juiz não resolverá o mérito quando: acolher a alegação de existência de convecção de arbitragem ou quando o juiz arbitral reconhecer a sua competência. ".

É meritório ressaltar que alguns procedimentos devem ser seguidos para que tal cláusula possua validade. Por exemplo, no caso de execução judicial, o artigo 515, inciso VIII do Novo Código Processual Civil versa que são títulos executivos, cujo o cumprimento dar-se-á de acordo com os artigos previstos neste Título: a sentença estrangeira homologada pelo STF.

Esta homologação deve ser requerida por ação de homologação a decisão judicial, bem como a decisão não judicial, que pela lei brasileira teria natureza jurisdicional, sendo está à ser executado no Brasil por meio de carta rogatória, conforme previsto no texto do artigo 960, parágrafo primeiro do Novo Código Processual Civil de 2015.

Em relação a eficácia da sentença estrangeira no Brasil, esta apenas se dará após a homologação de sentença ou a concessão do exequatur às cartas rogatórias conforme versa o artigo 961, parágrafo primeiro do Novo Código Processual Civil de 2015. Além das ações apresentadas, também serão indispensáveis os seguintes requisitos para a homologação:

(i). Ser proferida por autoridade competente (Art. 963, I, NCPC/2015);

(ii). Ser precedida de citação regular, ainda que a revelia (Art. 963, II, NCPC/2015);

(iii). Ser eficaz no país em que foi proferida (Art. 963, III, NCPC/2015);

(iv). Estar acompanhada de tradução oficial, salvo disposição que a dispense prevista em tratado (Art. 963, V, NCPC/2015);

(v). A medida de urgência concedida sem audiência do réu poderá ser executada desde que garantido o contraditório em momento anterior (Art. 962, §2, NCPC/2015); 
(vi). O cumprimento de decisão estrangeira far-se-á perante o juízo federal competente, a requerimento da parte, conforme as normas estabelecidas para o cumprimento de decisão nacional (Art. 965, Caput, NCPC/2015); e por fim

(vii). O pedido de execução deverá ser instruído com cópia autenticada da decisão homologatória ou do exequatur, conforme o caso (Art. 965, Parágrafo único, NCPC/2015).

Em verdade, a decisão poderá ainda ser parcialmente homologada (Art. 961, II, NCPC/2015) ou negada, na hipótese de a matéria ser considerada de competência exclusiva da autoridade judiciária brasileira, bem como a concessão do exequatur à carta rogatória em acordo com o artigo 964 e seu parágrafo único do Novo Código Processual Civil de 2015.

Existem ainda outros aspectos que vedam a homologação da decisão. Os mesmos estão dispostos no artigo 963 do Novo Código Processual Civil de 2015:

(i). Não ofender a coisa julgada brasileira (Art. 963, IV, NCPC/2015);

(ii). Não conter manifesta ofensa a ordem pública (Art. 963, VI, NCPC/2015).

Para termos uma ideia sobre o sucesso das homologações de laudos arbitrais realizadas nos últimos 10 anos, apresentaremos os seguintes dados (Takachi, 2015, Informação verbal ${ }^{14}$ ):

- De 2005 a 2009, dos 25 pedidos julgados, apenas 4 foram indeferidos;

- De 2010 a 2015, dos 40 pedidos julgados, apenas 5 foram indeferidos

Em uma análise mais aprofundada do ano de 2015, observamos que dos 8 pedidos julgados, 3 foram indeferidos, abaixo veremos a razão pelas suas não homologações:

- SEC 5782: STJ não homologou pelo fato de sentença arbitral ter sido anulada no país de origem (Art. 963, III, NCPC/2015);

- SEC 11593: STJ não homologou pois não foi comprovado a existência de cláusula compromissória (Art. 485, VII, NCPC/2015); e

\footnotetext{
14 Informação retirada do slide 26, aula 2 de Contratos Internacionais do curso de Pós-Graduação de Direito dos Contratos da PUC-Rio, no ano segundo semestre de 2015, ministrada pelo Professor William Takachi, Presidente da Comissão de Direito Internacional Privado da Ordem dos Advogados do Brasil - RJ- 57 Subseção
} 
- SEC 12236: STJ rejeitou homologação por entendeu que a sentença arbitral não foi proferida por autoridade competente (Art. 963, I, NCPC/2015).

Conforme observado nas informações apresentadas, verificamos que nos últimos dez anos, apenas quatorze por cento das homologações de Laudos Arbitrais foram indeferidas. Ao analisarmos mais de perto o ano de 2015, constatamos que todas homologações de Laudos Arbitrais recusadas se deram pelo não preenchimento das condições solicitadas pelo no Novo Código Processual Civil de 2015 e apresentadas neste estudo. Como podemos observar em nenhum dos casos a recusa se pelo mérito da coisa julgada.

Esta informação passa ao mercado uma grande credibilidade quanto a segurança jurídica aplicada no instituto da arbitragem no Brasil e explica por que cerca de $80 \%$ dos contratos internacionais possuem a cláusula compromissória Takachi, 2015, Informação verbal ${ }^{15}$ ).

15 Informação retirada do slide 21, aula 2 de Contratos Internacionais do curso de Pós-Graduação de Direito dos Contratos da PUC-Rio, no ano segundo semestre de 2015, ministrada pelo Professor William Takachi, Presidente da Comissão de Direito Internacional Privado da Ordem dos Advogados do Brasil - RJ- 57 Subseção 


\section{4. CLÁUSULA DE NÃO INDENIZAR NO DIREITO BRASILEIRO}

\subsection{Conceito}

A clausula de indenizar pode ser caracterizada com aquela em que as partes convencionam que a parte faltosa não possui o dever de reparação, ou seja, a cláusula exclui o dever de indenizar ou limita valor passível da indenização (VENOSA, 2013, P. 343). A mesma ainda pode ser definida como aquela em que ocorre a renúncia do direito a indenização. (AZEVEDO, 2004, p.201).

Ao analisarmos do ponto de vista técnico, a cláusula de não indenizar cessa uma das consequências da responsabilidade civil, sendo esta uma das consequências patrimoniais fruto do dever de indenizar. Assim, tal cláusula não evita a aparição da responsabilidade civil, mas limita os seus efeitos (BANDEIRA, 2016, p.113).

Grande parte doutrina possui o entendimento que a cláusula de não indenizar é uma cláusula de limitação de responsabilidade ou cláusula de irresponsabilidade, onde o seu objetivo é evitar o surgimento da responsabilidade.

No entanto, apesar de não estarem totalmente errados quanto ao fato de que a não aplicação de uma consequência da responsabilidade civil pode ser definida como a representação de uma limitação da reponsabilidade, não podemos alegar a inexistência de responsabilidade (BANDEIRA, 2016, p.114).

Assim, é importante nos diferenciarmos a causa de irresponsabilidade da causa de limitação de responsabilidade. A primeira, não se permite estabelecer através de vontade própria, cabe apenas a lei estabelecer e estipular quem deve ter a sua excepcionalidade (PERES, 2009, p.54). Ou seja, não é lícito as partes afastarem a responsabilidade, em outras palavras, apenas só será declarado irresponsável quem pratica delito em legítima defesa (DIAS, 1980, p.38-39).

É correto afirmar que a responsabilidade é de ordem pessoal e emanada pela ordem jurídica, consequência direta do ato ilícito, onde só a lei pode afastala (PERES, 2009, P. 54). Logo, não sendo lícito, cláusula pode ser considerada nula e sem efeito. 
Já na limitação de responsabilidade, as partes afastam apenas uma das consequências da responsabilidade civil, convencionando entre si a não obrigação do dever de indenizar da parte infratora (PERES, 2009, P. 54).

Ainda sobre a cláusula de não indenizar, não se pode afirmar que a mesma limita ou exonera o devedor de não cumprir a avença pactuada. Logo, a cláusula não pode ser considerada como o não cumprimento do vínculo, transformando a obrigação do devedor em simples obrigação natural (PERES, 2009, p.57).

\subsection{Doutrina}

Assim como o Código Civil de 1916, o Código Civil atual não regula especificamente sobre a Cláusula de Não Indenizar. Esta lacuna impõe a doutrina e a jurisprudência o dever de regular sobre tal tema, podendo levar a opiniões diferentes sobre o assunto (DIAS, 1980, p.37).

Podemos verificar que através dos artigos 408 ao 416 do Código Civil de 2002, em seu Capítulo V “Da Cláusula Penal” que o legislador permite a limitação das cláusulas do dever de indenizar, limitando assim a consequência da responsabilidade civil das partes (GOMES, 2006, p.186).

Logo, equitativamente a cláusula penal que predetermina a indenização em caso de prejuízo, a cláusula de não indenizar exclui ou limita o montante de eventual indenização em caso de dano, (VENOSA, 2013, p. 343)

Apesar de não regular expressamente a cláusula de não indenizar, conforme observado acima, o legislador acabou regulando o assunto em específicas situações como:

- A Evicção, onde no artigo 448 do código civil de 2002, permite que as partes através de cláusula expressa, reforçar ou diminuir a responsabilidade pela evicção;

- O contrato de adesão, onde por forçado artigo 424 do código civil de 2002 , veda a renuncia antecipada do aderente a direito resultante da natureza do negócio. Apesar de não ser objeto do nosso estudo, o contrato de adesão também é vedado pela Lei de Defesa do Consumidor (Lei $\mathrm{n}$. 8.078/90) artigos 24, 25 e 51, l; e

- Nos casos de Fortuito e Força Maior que por força do artigo 393 do código civil de 2002 permite o devedor não responder pelos prejuízos resultantes, com base no preceito de que nestes casos não era possível prever ou evitar o dano (GOMES, 2006, P.191). 
Ainda sobre o instituto do caso fortuito e força maior, através de formalização pactuada, poderão as partes reduzir o dever de indenizar através da assimilação com as hipóteses de tal matéria. Como exemplo podemos citar a falta de matéria-prima, greves, instabilidades econômicas, dentre outras que venham a ser consideradas restritivas a execução do negócio. Nestes casos o devedor não poderá ser responsabilizado pelos danos subsequente de tais atos, afastando assim o dever de indenizar. (PERES, 2009, p. 96-97).

Desta maneira não se pode olvidar que a cláusula de não indenizar é permitida na legislação brasileira, vide artigo 393 do código civil de 2002 . No entanto várias questões devem ser examinadas, devendo a cláusula ser analisada à luz dos princípios de direito contratual (VENOSA, 2013, p.344).

Em relação ao contrato de adesão, a doutrina possui o pensamento explicito sobre a matéria, nas palavras de Caio Mário temos o seguinte conceito:

\begin{abstract}
"adjeta a um contrato desta espécie (de adesão), a cláusula não pode ser admitida quando violadora da vontade do aceitante, ou revestindo a forma de uma imposição a ele dirigida. Seria, aliás, injurídico que aqueles que não têm a liberdade de deixar de contratar, por serem constrangidos pelas circunstâncias à aceitação do serviço, fossem tratados como aceitantes de uma convenção contrária aos seus interesses, determinada por uma imposição, a tartufamente interpretada como de livre aceitação, sob fundamento de que o serviço foi livremente aceito". 16
\end{abstract}

No entanto, mesmo nos casos em que se verifique a livre vontade das partes em pactuar a cláusula de não indenização, não significa que o gerador do dano não tenha que indenizar a outra parte nos casos de dolo ou culpa grave.

Também não se pode considerar a hipótese de que por não ter o dever de indenizar, a parte isenta pode se dar ao luxo de ficar desleixada em relação a sua obrigação, não seguindo as práticas e procedimentos comuns ao mercado. Caso isto ocorra a conduta praticada poderá ser considerada culpa grave, que pela doutrina é equiparada ao dolo (VENOSA, 2013, p.344-345).

Em resumo, conforme podemos constatar ao longo deste texto, a doutrina e a legislação vigente permitem a utilização da cláusula de não indenizar no direito pátrio.

\footnotetext{
${ }^{16}$ Caio Mario da Silva Pereira (Instituições de Direito Civil, 1972, p. 55)
} 


\subsection{Autonomia da Vontade}

A autonomia da vontade ou liberdade contratual, ou ainda autonomia privada já foi amplamente discutida na doutrina e por muitos doutrinadores definidos como por exemplo:

STRENGER,

"a autonomia da vontade como princípio deve ser sustentada não só como um elemento da liberdade em geral, mas como suporte também da liberdade jurídica, que é esse poder insuprível no homem de criar por um ato de vontade uma situação jurídica, desde que esse ato tenha objeto lícito". ${ }^{17}$

\section{OU RODRIGUES,}

"O Princípio da Autonomia da Vontade consiste na prerrogativa conferida aos indivíduos de criarem relações na órbita do direito, desde que se submetam as regras impostas pela lei e que seus fins coincidam como o interesse geral, ou não o contradigam.". 18

Por fim DINIZ,

"O principio da autonomia da vontade se funda na liberdade contratual dos contratantes, consistindo no poder de estipular livremente, como melhor convier, mediante acordo de vontades, a disciplina de seus interesses, suscitando efeitos tutelados pela ordem jurídica.' ${ }^{19}$

Tal princípio foi louvado no século XIX juntos com as ideias liberais da Revolução Francesa apresentam a ideia de que através de pactuação de instrumento jurídico (contrato) entre as partes, os mesmos estariam exteriorizando a vontade de ambos, tornando o contrato lei entre as partes. Ou seja, uma vez que o contrato que fosse pactuado, automaticamente iria adquirir força obrigatória de lei entre as partes (pacta sunt servanda). Vale lembrar que a autonomia da

\footnotetext{
${ }^{17}$ Irineu Strenger. (Da autonomia da vontade: Direito interno e internacional, 2000, p. 66.)

18 Silvio Rodrigues. (Dos Contratos e das Declarações Unilaterais de Vontade, 2007, p. 15.)

${ }^{19}$ Maria Helena Diniz (Teoria das Obrigações Contratuais e Extra Contratuais, 2008, p. 23)
} 
vontade deve ser restrita dentro dos princípios da lei e não deve beneficiar ou prejudicar terceiros ${ }^{20}$.

Ao longo dos séculos está ideia de liberdade total acabou por entrar em conflito com os interesses da sociedade. Está noção foi sendo ajustada ao longo do tempo e hoje ao analisarmos um contrato, não podemos apenas observar o que esta pactuado, se baseando apenas nos princípios clássicos do direito contratual, como a autonomia privada, a relatividade contratual e a obrigatoriedade do contrato. E necessário levar em conta outros princípios como a função social do contrato, a boa-fé objetiva e o equilíbrio contratual. Estes princípios modernos são respectivamente positivados no Código Civil de 2002 por seus artigos 421 onde a liberdade de contratar será exercida em razão e nos limites da função social do contrato, o artigo 422 o qual determina que os contratantes são obrigados a guardar, assim na conclusão do contrato, como em sua execução, os princípios de probidade e boa-fé e os artigo 317 o qual versa que quando, por motivos imprevisíveis, sobrevier desproporção manifesta entre o valor da prestação devida e o do momento de sua execução, poderá o juiz corrigilo, a pedido da parte, de modo que assegure, quanto possível, o valor real da prestação, além do artigo 478 que estipula que nos contratos de execução continuada ou diferida, se a prestação de uma das partes se tornar excessivamente onerosa, com extrema vantagem para a outra, em virtude de acontecimentos extraordinários e imprevisíveis, poderá o devedor pedir a resolução do contrato. Os efeitos da sentença que a decretar retroagirão à data da citação.

Logo, para não perder a sua força obrigatória, o negócio jurídico deve contemplar a estabilidade de diversas características, sobretudo de cunho econômico (COUTO E SILVA, 2007, p. 108).

Ao focarmos nos contratos comerciais e paritários, objeto deste estudo, podemos afirmar que tais instrumentos são formados através de extensivas rodadas de negociação, estabelecendo entre si as melhores práticas e condições para o negócio, os valores de bens, riquezas e serviços, analisando os custos e riscos envolvidos, chegando assim a um valor justo entre as partes, onde elas poderão livremente expressaram a sua manifestação de vontade.

Conforme dissertado anteriormente, os contratos da indústria de óleo e gás são extremamente complexos, dotados de grande especificidade e características próprias, fruto de exaustivas negociações que em muitos casos chegam a levar

${ }^{20}$ Antônio Junqueira Azevedo (Revista dos Tribunais $n^{\circ} 750,1998$, p. 115) 
meses para se possa chegar a uma redação comum e aceitável por ambas as partes.

Assim sendo, não há de se pensar que houve algum tipo de sobreposição de uma parte com a outra, mesmo quando existe uma grande diferença em relação ao poderio econômico ou do poder de negociação entre elas. Nestes casos podemos admitir que houve uma expressão da autonomia da vontade positivada no contrato ainda mais forte.

Logo, ao analisarmos a cláusula "Knock for Knock", não há de se falar que a autonomia da vontade sobrepôs algum dos outros princípios modernos do contrato. Esta constatação se dá uma vez que tal cláusula visa a alocação dos riscos do negócio, onde as partes têm como objetivo um melhor aproveitamento dos esforços aplicados, além de obter vantagem econômica, retirando a obrigação de indenizar no caso de culpa.

Portanto é incorreto afirmar que tal cláusula fere os princípios modernos do contrato. Esta afirmação é correta, uma vez que não a cláusula "Knock for Knock" não desrespeita o princípio da Boa-fé, pois as partes negociam com honestidade, lealdade e probidade, tampouco infringe a Função Social do contrato, pois tal cláusula não é abusiva e nem causa dano a parte contrária ou a terceiros e por fim, não viola o equilíbrio contratual, posto que uma ou ambas as partes adquirem um menor risco da atividade obtendo em contrapartida uma vantagem correlata, como exemplo um melhor preço do bem ou serviço ou um menor custo do seguro a ser contratado, ou seja, obtendo uma vantagem comercial, sendo assim incorreto afirmar que tal cláusula provoca um desequilíbrio nas prestações e obrigações das partes, gerando um desequilíbrio contratual.

Por fim, devemos lembrar que o pacta sunt servanda ainda é a regra e o afastamento de uma cláusula ou uma revisão da mesma deve ser justificada.

Conforme podemos observar, não há que se falar em abusividade da cláusula "Knock for Knock", uma vez que a mesma respeita a lei e não fere os outros princípios modernos do contrato.

\subsection{Requisitos para validade da Cláusula de Não Indenizar e Suas Restrições.}

Ao analisarmos os requisitos necessários para validarmos a cláusula de não indenizar, a primeira constatação que temos é de que não existe instrumento no ordenamento legal que proíba a utilização na mesma. Estas vedações apenas 
são encontradas em algumas leis especiais com o caráter de excepcionalidade, como por exemplo algumas restrições encontradas no Código de Defesa do Consumidor (AVELAR, 2012, p.140).

Parte da doutrina defende que a vedação da cláusula de não indenizar infringe a liberdade de contratar, consequentemente fere o princípio da autonomia da vontade, argumentando que a sua interdição só deva ser admitida em casos especiais onde ocorre a proibição legal (AVELAR, 2012, p.140).

Após análise, verificamos que em alguns casos, a lei admite a possibilidade da cláusula de não indenizar, esta afirmação é atestada pela letra do artigo 448 do Código Civil de 2002, onde é permitido as partes, por cláusula expressa, reforçar, diminuir ou excluir a responsabilidade pela evicção. (AVELAR, 2012, p.142). Outro exemplo que podemos considerar é o artigo 946 do Código Civil de 2002, onde o mesmo permite que as partes fixem o valor do montante indenizatório, contemplando também a possibilidade da cláusula de não indenizar, conforme versa o seu texto: "Se a obrigação for indeterminada, e não houver na lei ou no contrato disposição fixando a indenização devida pelo inadimplente, apurar-se-á o valor das perdas e danos na forma que a lei processual determinar" (BANDEIRA, 2016, p.129).

Por fim, vale citar o artigo 51, inciso I do Código de Defesa do Consumidor que em uma diferente interpretação admite-se a cláusula de não indenizar em situações especiais quando o consumidor for pessoa jurídica, conforme seu texto (BANDEIRA, 2016, p.129):

\footnotetext{
"São nulas de pleno direito, entre outras, as cláusulas contratuais relativas ao fornecimento de produtos $\mathrm{e}$ serviços que:

I - Impossibilitem, exonerem ou atenuem a responsabilidade do fornecedor por vícios de qualquer natureza dos produtos e serviços ou impliquem renúncia ou disposição de direitos. Nas relações de consumo entre o fornecedor e o consumidor pessoa jurídica, a indenização poderá ser limitada, em situações justificáveis; "21
}

Conforme podemos constatar, podemos pressupor que a cláusula de não indenizar é válida, pois não existe nada na lei que diga o contrário. No entanto para a sua aplicação devemos verificar em quais casos a lei veda a sua aplicação. Dissertaremos ao longo deste capítulo alguns destes exemplos.

\footnotetext{
${ }^{21}$ Artigo 51, I do Código de Defesa do Consumidor
} 
O primeiro caso a ser analisado é em relação a vulnerabilidade de uma das partes. Quando não se verifica uma relação paritária entre as partes, a mesma caracteriza-se com uma imposição unilateral de vontade, causando prejuízo a parte mais fraca (PERES, 2009, p.134).

Caso tal situação fosse permitida, teríamos um abalo do equilíbrio contratual, sem falar na violação do princípio função social do contrato e na infração do princípio da Boa-fé, logo neste caso é vedada a utilização da cláusula de não indenizar.

O segundo caso se refere aos contratos de adesão, contrato este definido pelo artigo 54 do Código de Defesa do Consumidor como um contrato de cujas cláusulas tenham sido aprovadas pela autoridade competente ou estabelecidas unilateralmente pelo fornecedor de produtos ou serviços, sem que o consumidor possa discutir ou modificar substancialmente seu conteúdo.

Independentemente de o contrato de adesão ser tido primeiramente sua tutelada tratada pelo Código de Defesa do Consumidor, esta está matéria não é apenas do interesse dos consumidores.

Apesar de em sua maioria dos contratos de adesão serem efetivados no campo dos consumidores, este modelo é percebido em toda esfera contratual (TEPEDINO; BARBOZA; MORAES, 2006, p.24). Esta afirmação tem subsidio do Enunciado 171 da III da Jornada de Direito Civil que expressa em seu texto o entendimento de que o contrato de adesão, mencionado nos artigos 423 e 424 do novo Código Civil, não se confunde com o contrato de consumo.

Os contratos de adesão são largamente utilizados, seja ele entre pessoas físicas ou entre pessoas jurídica, devido a vantagem gerada para as partes, uma vez que ambas as partes necessitam de agilidade que os contratos de modelo padrão, ou contratos de adesão possuem (AVELAR, 2012, p. 160).

Contudo, a cláusula de não indenizar é vedada aos contratos de adesão no ordenamento brasileiro. Esta proibição expressa se dá por força do artigo 424 do Código Civil de 2002, o qual versa, "Nos contratos de adesão, são nulas as cláusulas que estipulem a renúncia antecipada do aderente a direito resultante da natureza do negócio.". Conforme já dissertado neste texto, o direito a indenização é consequência do dano causado por outrem, logo ao vedar a possibilidade de renúncia de direito, o artigo 424 proíbe a cláusula de não indenizar.

Durante a III Jornada de Direito Civil, no Enunciado 167, foi reconhecido uma proximidade entre artigo 424 do Código Civil de 2002 com o artigo 51, I do Código de Defesa do Consumidor, onde em seu texto expressa: 
"Com o advento do Código Civil de 2002, houve forte aproximação principiológica entre esse Código e o Código de Defesa do Consumidor, no que respeita à regulação contratual, uma vez que ambos são incorporadores de uma nova teoria geral dos contratos “

Apesar de existir proximidade entre os regramentos do Código Civil e o Código de Direito do Consumidor, segundo o entendimento Cláudia Lima Marques, Antônio Herman V. Benjamin e Bruno Miragem o Código Civil regula os iguais, assim as cláusulas abusivas estarão presentes em sua maioria nos contratos de adesão enquanto o Código de Defesa do Consumidor regula os diferentes, com o pressuposto que de que o consumidor é parte vulnerável (AVELAR, 2012, p.160).

Como podemos constatar neste modelo de contrato existe uma imposição unilateral de vontade, o qual não permitir ao aderente a possibilidade de expressar a sua vontade perante a determinado assunto, ficando a sua liberdade restrita a aderir ou não o produto, serviço ou negócio ofertado. Neste caso podemos admitir que a sua vulnerabilidade é ainda maior.

O terceiro vedação se refere a ordem pública e normas congentes. Antes de falar da vedação, é necessário conceituarmos a expressão "Ordem Pública". A doutrina apresenta dificuldade ao definir o tal conceito, no entanto a mesma entende que não existe maior subterfúgio do que limitar ou invalidar o dever de indenizar quando esta atinge a ordem pública, os bons costumes ou na ocorrência de situações em que já exista vedação de normas congentes (PERES, 2009, p.142-143). Em verdade, o que se observa em comum nas diversas definições dos doutrinadores é que a ordem pública se conceitua por indicar o domínio de oportunos interesses sociais em detrimento das preleções individuas das partes envolvidas negócio jurídico (BANDEIRA, 2016, p.130-131).

Podemos citar como exemplo a vedação a cláusula de não indenizar nas relações de trabalho. Imaginamos uma situação onde o empregado venha sofre um dano, a restrição a indenização neste caso iria contra ao preceito originários do contrato de trabalho, onde é vedada a renúncia de direitos, uma vez que se entende que o empregador apresenta uma posição superior frente ao empregado, necessitando assim de uma maior proteção (PERES, 2009, p.145).

Outro exemplo se dá pela impossibilidade de restringir a indenização aos danos pessoais e dos danos a integridade psicofísica das pessoas naturais, uma vez que estas vedações estaria em contraditório ao princípio da dignidade da pessoa humana (PERES, 2009, p.147). Como princípio fundamental do 
ordenamento jurídico brasileiro, positivada no artigo primeiro, inciso III da Constituição Federal de 1988, o princípio a dignidade da pessoa humana não pode ser sobreposto a nenhuma norma ou qualquer decisão pactuada entre privados, sendo assim privada a sua vedação. O entendimento de que a cláusula de não indenizar estaria vedada nos casos de dano pessoais e psicofísicos é compartilhada por Antonio Pinto Monteiro:

"Estando em causa o bem da incolumidade
pessoal, não será admitida cláusula de
irresponsabilidade, por evidentes razões de
ordem pública, exigindo o o respeito da pessoa
humana seja sancionada qualquer imprudência
do lesante que cause danos pessoais,
prevenindo-se assim atitudes negligentes em fase
les plus sacrés, cuja proteção não poderá ser
afectada, aliás, por considerações de mercado"22.

Ainda sobre o tema, é importante destacar o dano moral e a dicotomia em sua aplicação, nas pessoas físicas e jurídica. Apesar de estar jurisprudencialmente consolidado o entendimento de que é passível de pessoa jurídica sofrer dano moral, vide súmula 227 do Superior Tribunal de Justiça, o princípio desta aplicação não pode ser a do dano a pessoa humana. Neste caso a vedação a indenização na estaria subsidiada pela violação a ordem publica, que como visto, defende a integridade psicofísica da pessoa humana, assim a vedação a cláusula de não indenizar poderia em alguns casos ser aceita. Assim, apesar de entender que a pessoa física pode sofre dano moral, também precisamos entender que a lesão se deriva de objeto de uma cláusula que restrinja ou vede a indenização (BANDEIRA, 2016, p.131-132).

Como quarto exemplo, podemos elencar a vedação da cláusula de não indenizar nas relações consumeristas. É importante ressaltar que aqui dissertaremos sobre o consumidor como pessoa física, como podemos ver no início deste capítulo, existe a possibilidade da aceitação da cláusula de não indenizar quando este for pessoa jurídica.

Por força do artigo 25 do Código de Defesa do Consumidor, é vedada a estipulação contratual de cláusula que impossibilite, exonere ou atenue a

22 Antônio Pinto Monteiro (Cláusulas Limitativas e de Exclusão de Responsabilidade Civil, 2003, p. 308) 
obrigação de indenizar prevista nesta e nas seções anteriores, ou seja, é vedada ao fornecedor a utilização de cláusula de irresponsabilidade nos casos de vício do produto. Também fica vedado a exoneração contratual do fornecedor quanto a garantia legal, positivada no artigo 24 do Código de Defesa do Consumidor através de seu texto: "A garantia legal de adequação do produto ou serviço independe de termo expresso, vedada a exoneração contratual do fornecedor.".

A mesma vedação ocorre no artigo 51, I do Código de Defesa do Consumidor, onde em seu texto considera nula cláusula em que ocorrera renuncia de direito antecipado, neste caso sendo considerada cláusula abusiva, conforme seu texto:

\footnotetext{
"São nulas de pleno direito, entre outras, as cláusulas contratuais relativas ao fornecimento de produtos e serviços que:

I - Impossibilitem, exonerem ou atenuem a responsabilidade do fornecedor por vícios de qualquer natureza dos produtos e serviços ou impliquem renúncia ou disposição de direitos. Nas relações de consumo entre o fornecedor e o consumidor pessoa jurídica, a indenização poderá ser limitada, em situações justificáveis".
}

O quinto caso a ser analisado é em relação a transporte de pessoas e coisas. Por força do caput do artigo 734 do Código Civil de 2002, "O transportador responde pelos danos causados às pessoas transportadas e suas bagagens, salvo motivo de força maior, sendo nula qualquer cláusula excludente da responsabilidade.". Logo, como podemos constatar, fica vedada a utilização da cláusula de não indenizar. Contudo devemos nos atentar para o parágrafo primeiro parágrafo do artigo supracitado, onde é permitido ao transportador limitar o valor da indenização ao valor da bagagem lesada ou extraviada, ficando esta exceção apenas limitada ao valor da bagagem, e a mais nenhum outro dano, conforme descrito em seu texto: "É lícito ao transportador exigir a declaração do valor da bagagem a fim de fixar o limite da indenização.”. É importante ressaltar que para obter este "direito", deve o transportador exigir a declaração do valor da bagagem, caso negativo o valor deverá ser estipulado pelo lesado, amparado pelo princípio da razoabilidade e da boa-fé e determinado por autoridade competente. 
$\mathrm{Na}$ seara do transporte de coisas, o artigo 750, combinado com o artigo 744 do Código Civil de 2002, também limita o valor a ser indenizado, vide texto dos artigos supracitados respectivamente:

\begin{abstract}
"A responsabilidade do transportador, limitada ao valor constante do conhecimento, começa no momento em que ele, ou seus prepostos, recebem a coisa; termina quando é entregue ao destinatário, ou depositada em juízo, se aquele não for encontrado"; e

"Ao receber a coisa, o transportador emitirá conhecimento com a menção dos dados que a identifiquem, obedecido o disposto em lei especial.".
\end{abstract}

Ainda neste contexto, aos artigos 14 e 15 da Lei do Transporte Rodoviário de Cargas (Lei 11.442/07), também limitam o montante indenizatório, vide seus textos:
"A responsabilidade do transportador por prejuízos resultantes de perdas ou danos causados às mercadorias é limitada ao valor declarado pelo expedidor e consignado no contrato ou conhecimento de transporte, acrescido dos valores do frete e do seguro correspondentes.

Parágrafo único. Na hipótese de o expedidor não declarar o valor das mercadorias, a responsabilidade do transportador será limitada ao valor de 2 (dois) Direitos Especiais de Saque DES por quilograma de peso bruto transportado"23; e

"Quando não definida no contrato ou conhecimento de transporte, a responsabilidade por prejuízos resultantes de atraso na entrega é limitada ao valor do frete" 24 .

Em ambos os casos, apesar de vedada a cláusula de não indenizar, podemos admitir que a prática de limitação do montante indenizatório é permitida, desde que tal valor não seja irrisório (AVELAR, 2012, p.119).

${ }^{23}$ Artigo 14 da Lei 11.442/07

${ }^{24}$ Artigo 15 da Lei 11.442/07 
Ainda em relação ao transporte, a vedação a não indenização é confirmada pela Súmula 161 do Supremo Tribunal Federal onde em seu texto afirma que "em contrato de transporte, é inoperante a cláusula de não indenizar.".

Por fim, o último caso abordado neste escuto se dedica a vedação da cláusula de não indenizar nos casos de dolo e da culpa grave.

Em relação ao primeiro, a simples possibilidade de assumirmos a vedação ao dolo, acarretaria na admissibilidade da dispensa da prestação e obrigação pactuada, não se traduzindo em indenização ou dever de reparar, sendo aceita previamente impunidade a má fé (CAVALIERI FILHO, 2004, p. 506), podendo conjuntamente admitir que tal condição infligiria o princípio da boa-fé. Também é correto afirmar que a possibilidade de admissão do dolo ira esbarrar no preceito ordem pública, a despropósito dos bons costumes e no que diz respeito ao ordenamento tutelar a exoneração de indenização de avença pactuada entre as partes. Conforme já descrito neste capítulo, é vedada a cláusula de não indenizar quando esta infringe a ordem pública.

Em relação a culpa grave, apesar de parte da doutrina admitir que é admissível a cláusula de não indenizar para a mesma, a grande maioria é contrária, tendo como principal argumento o não incentivo à negligência e a imprudência fora dos limites da razoaviabilidade (PERES, 2009, p.176). Em apoio a esta ideia, Sergio Cavalieri Filho discorre:

"A culpa grave, por sua vez, revela negligência extrema, grosseira ausência de vigilância, em que até o homem menos cuidadoso não incide nos seus próprios negócios. A interdição da cláusula de não indenizar, em casos tais, é exigência da moral e da boa-fé. 25 "

25 Sergio Cavalieri Filho (Programa de Responsabilidade Civil, 2004, p. 506) 


\section{5. DEFESA DA UTILIZAÇÃO DO MODELO "KNOCK FOR KNOCK"}

\subsection{Gerenciamento do Risco e a Cláusula “Knock for Knock"}

A exploração e produção de óleo e gás é uma das atividades mais perigosas do mundo, talvez apenas comparada a indústria ao setor de mineração. Quando falamos da atividade de exploração e produção no offshore, este risco ainda é maior, pois aumenta a dificuldade de evacuação da área de operação, além da inclusão de novos atores como as embarcações de logística, rebocadores, Unidades de Produção - FPSOs ${ }^{26}$, helicópteros, entre outros, logo é de extrema importância realizar o gerenciamento de risco com a maior competência possível.

Podemos elencar alguns riscos inerentes à atividade:

- Contaminação ou intoxicação por gás sulfúrico ou outros hidrocarbonetos voláteis;

- Emissão de gases e vapores;

- Vazamentos

- Explosões;

- Incêndios;

- Doenças de pele e dermatites

- Contaminação do meio ambiente, dentre outros;

A seguir podemos ver observar imagem do acidente com a plataforma de perfuração Deepwater Horizon, ocorrido no Golfo do México, onde a empresa exploradora, British Petroleum contratou a empresa de perfuração Transocean para perfurar um poço exploratório no Campo de Macondo que como

\footnotetext{
${ }^{26}$ FPSO - Floating Production Storage and Offloading (Unidade de Produção Armazenamento e Descarregamento de Óleo)
} 
consequência de má orientação e não observância das melhores práticas do mercado e aos riscos evidentes, ocasionou o maior acidente ambiental da história da indústria, tendo como consequência a morte de onze funcionários ${ }^{27}$ e setecentos e oitenta milhões de litros de óleo vazados ${ }^{28}$ no mar. Após este acidente a British Petroleum foi condenada a pagar vinte bilhões e oitocentos milhões de dólares americanos ${ }^{29}$.

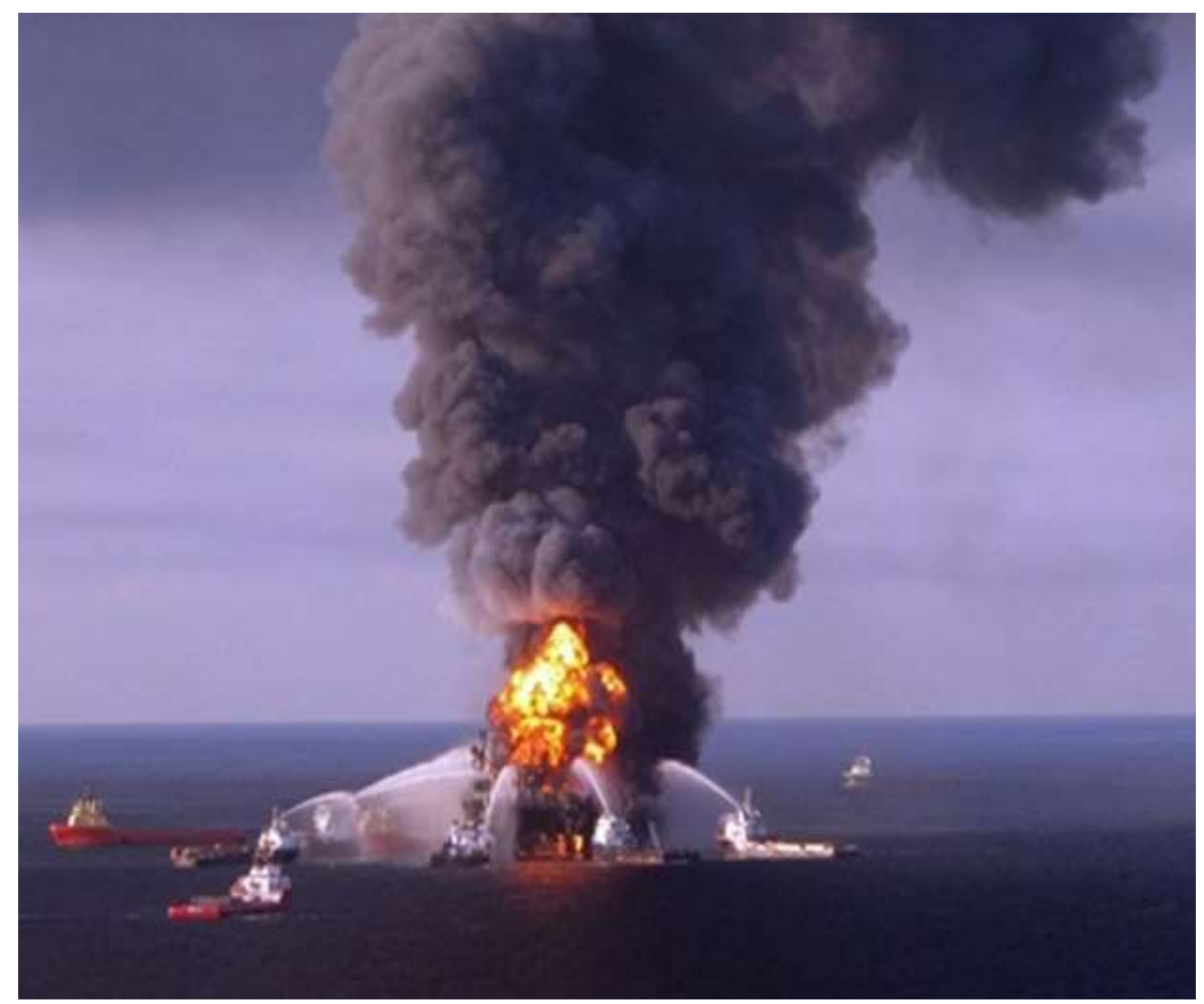

Figura 1 - Acidente no Campo de Macondo no Golfo do México - Estados Unidos Fonte: Globo.com

$\mathrm{Na}$ ideia de que a responsabilidade civil deve ser apreciada economicamente, os renomados senhores Guido Calabresi, Ronald Coase, propõem que seja abandonada a simples ideia de que a responsabilidade civil fique limitada ao dano causado pelo lesante ao lesado e incluirmos neste ambiente a visão de avaliar os custos e as vantagens assumidas pelas partes na ocorrência de danos (MENDONÇA, 2012, p.52).

\footnotetext{
${ }^{27}$ Fonte: Site da Revista Brasil Energia em 21/05/2015

${ }^{28}$ Fonte: Site da Revista VEJA em 02/08/2010

29 Fonte: Site da Revista Brasil Energia em 21/05/2015
} 
Também é defendido que a responsabilidade civil não fique presa a sua função de reparar os danos, mas também atue como ferramenta de alocação dos riscos e na atenuação dos danos e dos custos derivados (MENDONÇA, 2012, p.53).

$\mathrm{Na}$ teoria o risco deve ser alocado com base no cuidado, custódia e controle de pessoas e bens. A alocação de risco pode ser unilateral ou recíproca. Na primeira, apenas uma parte fica responsável por indenizar a outra por danos relativos a certos bens, pessoas e interesses; já na segunda hipótese, ambas as partes se indenização mutualmente por danos específicos relativos a certos bens, pessoas e interesses específicos.

O modelo "Knock for Knock" é considerada uma alocação recíproca, onde não necessariamente a proporção dos riscos são iguais. Em suma, o "Knock for Knock" constrõem uma divisão simplificada do risco, onde as partes concordam em se auto indenizar nos casos em que ocorra prejuízos aos seus funcionários e bens, portanto o modelo aqui estudado tem como princípio mitigar os riscos inerentes as atividades da operação, através de sua devida alocação e consequentemente com um ganho decorrente da redução dos custos.

A alocação do risco está intimamente ligada a condição de preço, quando a contratante assumi maior risco, consequentemente obterá um menor preço, o mesmo ocorre de maneira inversa caso a contratada assuma este risco. Como exemplo podemos citar a seguinte situação:

- A empresa contratante, o qual possui a concessão de determinada área concedida pela Agência Nacional de Petróleo e Biocombustíveis (ANP) para realizar atividades de exploração e produção, possui entre suas obrigações, por força do Órgão Ambiental (IBAMA) a obrigada a manter embarcações de oil spill ${ }^{30}$ dedicadas, além de possuir um plano de contingência de emergência individual com todos os recursos necessários para atuar em caso de vazamento de óleo no mar, independentemente se a causa de tal acidente tenha ocorrido por terceiros contratados pela empresa;

- Imaginemos que a mesma contrate empresa de perfuração para realizar a perfuração de um poço de certa profundidade e que em tal contrato se impute a responsabilidade em caso de vazamento a empresa contratada

${ }^{30}$ Embarcação responsável pela contenção e recolhimento de óleo em caso de vazamento no mar 
deve ser responsável por reparar o dano, uma vez que a mesma deu causa para o fato;

- Nesta situação, para mitigar o risco, a empresa contratada iria contratar embarcações oil spill além de todos os recursos necessários para atuar em caso de vazamento;

- Como a empresa não pode operar em prejuízo, a mesma imputará o custo de manter esta estrutura no preço do serviço oferecido, tornando-o mais caro e consequentemente a empresa contratante possuirá um custo duplicado na atividade.

Neste contexto de alocação de risco, podemos considerar a indenização como uma promessa de proteção de eventos desfavoráveis (riscos especificados) que podem ocorrer ao longo do contrato, independentemente de quem estiver dado causa, com exceção das situações de dolo e culpa grosseira, conforme já dissertado neste estudo.

Para determinar a alocação devemos utilizar o critério de que possui maior facilidade de gerenciar o risco em particular. Uma vez identificado a parte, esta deve assumir a responsabilidade de indenização em caso de dano inerente ao risco percebido. Em visão oposta, caso a parte não consiga controlar o risco ou seu gerencialmente seja muito difícil ou até mesmo impossível, a outra parte deve assumir o custo de indenização.

Voltemos ao exemplo acima, durante a atividade de perfuração a empresa contratada é responsável por exercer a atividade de perfurar um poço, não sendo de responsabilidade "desenhar" o poço, definir a sua direção e nem possuir geólogos para identificar quais zonas geológicas irá passar e quais riscos que cada zona geológica possui, assim, como não é responsável pela cimentação do poço ${ }^{31}$. Neste caso fica impossível a empresa de perfuração gerenciar uma má cimentação em uma zona de produtora de gás, o que pode ocasionar um blowout $^{32}$, causando explosão e vazamento de óleo no mar, devendo assim este risco ser assumido pela empresa contratante e consequentemente a possível indenização.

\footnotetext{
${ }^{31}$ Atividade de cimentação basicamente consiste no preenchimento do espaço anular entre os tubos e a parede da formação e tem como principal finalidade a união da tubulação de revestimento com a parede do poço, além do objetivo de formar um tampão de selo no fundo do poço ou para corrigir desvios do furo durante a perfuração.

32 Fluxo descontrolado de hidrocarbonetos, gás ou água saindo de um poço de petróleo devido a alguma falha no seu sistema de controle de pressão
} 
No caso inverso imaginemos a quebra de uma estrutura da torre de perfuração. Neste caso a manutenção e integridade, além do seu reparo são de responsabilidade e o risco de fácil administração por parte da empresa de perfuração, devendo ficar esta responsável por possível indenização do dano, mesmo que este tenha sido por culpa da contratante. Mais uma vez é importante reafirmar que não são considerados os casos de dolo ou culpa grave.

Logo, podemos afirmar que na prática a contratada é a melhor entidade para gerir o risco de lesões ou morte de seus próprios funcionários e de seus próprios bens, uma vez que a mesma limitar a exposição do risco de seu funcionário, forma-lo de forma adequada, condizentes as melhores práticas de segurança, contrair seguro de indenização aos seus funcionários, realizar manutenção periódica e com a devida destreza os seus matérias e equipamentos, além da aquisição de seguro para os seus bens. O mesmo princípio vale para a contratante.

Outro custo relevante que é impactado diretamente na alocação do risco, são os custos referentes aos seguros. Uma vez que os riscos são facilmente identificados e alocados corretamente o risco de tal ocorrência diminui e consequentemente o valor do seguro será menor. Adicionalmente a redução do valor do seguro, a alocação correta do risco, não permite o duplo seguro de uma coisa ou pessoa. Uma vez reduzidos os custos, teremos uma operação mais barata para ambas as partes.

Para que tal modelo "Knock for Knock" funcione é necessário que nestes contratos as empresas contratarem os seguros excluído a possibilidade de subrogação contra a empresa contratada ou contratante.

\subsection{Razão de utilização da Cláusula "Knock for Knock" pela Indústria Petrolífera}

Um dos grandes motivos pela predileção pelas partes envolvidas na indústria do petróleo para com os contratos que possuem a cláusula "Knock for Knock" se dá complexidade dos serviços o que em caso de disputas litigiosas necessitará de investigações complexas, que podem contemplar falhas, além de gerar demorados e dispendiosos custos judiciais.

A utilização do mesmo visa eliminar tais disputas apenas lendo o contrato, verificando quem é o responsável por determinado risco em caso de dano, sem a necessidade de levar ao judiciário ou a corte arbitral. 
Dependendo da disputa, o tempo para o seu julgamento pode demorar meses e até anos, o que paralisa ou inviabiliza uma operação, visto que em uma operação de exploração ou produção gastam-se em média mais de hum milhão de dólares americanos por dia. Logo, uma vez definido a responsabilidade não há de se discutir sobre qual parte dever ser responsabilizada pelo prejuízo ocorrido.

Outro motivo é o de viabilizar a atividade em si. Vamos imaginar que por ventura a empresa que foi contratada para operar um FPSO, durante a execução de suas atividades, acaba por um erro de operação, não caracterizado dolo ou culpa grave cause a parada definitiva da produção um poço causando um enorme prejuízo a empresa contratante. Caso não existisse a cláusula "Knock for Knock" a mesma teria que reparar o dano ao cliente, tendo a necessidade de perfurar outro poço ou poços que venham a produzir a mesma vazão de óleo que o poço anterior produzia. Neste caso quando a empresa prestadora de serviço fosse assinar o contrato, a mesma iria imputar o seu preço o possível custo de ter que perfurar outro poço ou poços em razão do risco assumido pela mesma, o que nesta concepção tornaria o preço do serviço inviável para a sua contratação e como consequência inviabilizaria todas a atividade em si.

Nos casos de alocação de risco é importante lembrarmos do princípio risco vs. retorno. É princípio já extremante difundido, disserta que quanto maior for o risco assumido, maior será o retorno obtido.

Ao transferirmos este princípio para as relações entre os atores do mercado petrolífero, observamos um cenário onde as empresas prestadoras de serviço apesar de assumirem um menor risco, comparado ao contratante, os mesmos poderão no máximo alcançar o ganho entre as partes no contrato. Ao analisarmos as chamadas empresas operadores, empresas detentoras das concessões de exploração e produção, constatamos que no caso de descoberta de um campo produtor de petróleo e ou gás, as mesmas obterão ganhos ilimitados, sendo apenas restringido pelo potencial de produção do campo, consequentemente a empresa operadora acabará por assumir maiores riscos, comparado as empresas prestadoras de serviço.

É importante ressaltar que a cláusula "Knock for Knock" não tem como objetivo repartir igualmente os riscos inerentes a operação, mas sim aloca-los da melhor forma possível, levando em consideração a sua viabilidade, custos e facilidade no gerenciamento do determinado risco.

Conforme já citado no item acima outra razão para se utilizar o modelo "Knock for Knock" é a redução nos custos da atividade para ambas as partes. Em concordância com o anteriormente descrito, uma vez adotado o modelo "Knock 
for Knock", o mesmo permitirá que não ocorra a dupla oneração dos custos necessários para se evitar danos e acidentes, bem como o duplo dispêndio em relação as contratações dos seguros inerentes as atividades, conforme já explicado.

Por fim, temos com último objetivo da utilização da cláusula "Knock for Knock" o aumento da segurança nas atividades realizadas na exploração e produção de óleo e gás.

A primeira impressão ao analisarmos tal afirmativa, podemos pensar que ao isentar uma parte de reparar o dano que vier a causar a outra parte, a mesma poderá "relaxar" e não se preocupar com os riscos que tal atividade pode acarretar. Entretanto, a indústria como um todo entende que não existe melhor indivíduo do que o próprio para analisar e mitigar os riscos inerentes a sua atividade e ao seu patrimônio, tomando para si a responsabilidade de manter o seu ambiente de trabalho mais seguro, uma vez que caso ocorra algum prejuízo em sua atividade o mesmo deverá arcar com os custos de reparar. Logo, se entende que as operações como um todo se tornaram mais segura, mantendo a atenção de cada indivíduo na a sua atividade, não a desperdiçando esforço e custos em outros assuntos que não sejam nos que possui maior conhecimento técnico e interesse.

\subsection{Defesa da sua utilização da Cláusula "Knock for Knock" perante ao ordenamento brasileiro}

Conforme podemos constatar no capítulo anterior, não existe norma expressa no ordenamento legal brasileiro que proíba a utilização da cláusula de não indenizar. Esta vedação é apenas percebida na verificação das leis especiais.

Afirmando que a cláusula "Knock for Knock" é uma cláusula de não indenizar e ao analisarmos os exemplos destas vedações, constatamos que nenhuma delas se encaixam nos contratos da indústria do óleo e gás onde a cláusulas “Knock for Knock" é largamente utilizada.

Não há de se falar em relações consumerista nestes contratos, tão pouco afirmar que os mesmos são de adesão, na medida que os contratos são extensamente debatidos e negociados até que se chegue a um texto em comum.

A cláusula em si também não traz prejuízo à ordem pública, pois não fere o princípio da dignidade humana e não veda a indenização aos danos pessoais e 
aos danos psicofísicos, apenas o aloca entre o ressarcimento das indenizações entre as partes.

Mesmos nos contratos de embarcações onde as mesmas são utilizadas para diversas tarefas entre elas o transporte de carga, a extensão da cláusula "Knock for Knock" fica restrita ao dano a embarcação e as unidades fixas ou flutuantes ${ }^{33}$ das empresas contratantes, não abrangendo a carga que as mesmas transportam. Assim, a cláusula "Knock for Knock" nestes casos não ferem as normas brasileiras quanto a indenização nos casos de perda, extravio, roubo e dano que conforme descrito no capítulo são de responsabilidade da empresa transportadora.

Finalmente, conforme já abordado no Capítulo II, a cláusula "Knock for Knock" não contempla os casos de dolo e culpa grave, não violando a ordem pública e nem o princípio da Boa-Fé.

Assim, uma vez que o artigo 5, inciso II da Constituição Federal de 1988 versa que "ninguém será obrigado a fazer ou deixar de fazer alguma coisa senão em virtude de lei" e o artigo 5, inciso XXXIX da mesma, versa que "não há crime sem lei anterior que o defina, nem pena sem prévia cominação legal”, podemos afirmar que a cláusula "Knock for Knock" é aceitável no ordenamento pátrio.

\subsection{Jurisprudência}

Até o presente momento, não se tem registro de julgados na esfera do judiciário brasileiro que contemplem os contratos que possuam a cláusula "Knock for Knock", ou seja, até hoje não ouve demanda ao judiciário brasileiro para o julgamento de causas onde existam a ocorrência desta cláusula.

Entretanto este panorama é diferente quando se trata da esfera arbitral. A grande maioria dos contratos da indústria petrolífera apresentam a existência de cláusula compromissória, elegendo a arbitragem como local para receber possíveis disputas entre as partes.

Esta decisão tem sido quase que majoritária pois na grande maioria dos casos, a jurisprudência demonstra que maior parte dos árbitros leva em consideração os preceitos da lex petrolea.

O conceito lex petrolea foi observado primeiramente no tribunal arbitral que julgou o caso ARAMCO vs. Arábia Saudita em 1958. Nesta ocasião o tribunal

\footnotetext{
${ }^{33}$ Entende-se como unidades fixas ou flutuantes sondas de perfuração, plataformas de produção e
} qualquer unidade em alto mar pertencente a empresa exploradora e produtora de petróleo e gás 
entendeu que o julgamento deveria ocorrer levando em consideração lei pátria em conjunto com os princípios gerais do direito e pelos costumes e pelas boas práticas da indústria petrolífera (DOLLINGER E TIBURCIO, 2003, p.104).

$\mathrm{Na}$ ocasião supracitada o tribunal entendeu que a lex petrolea é uma derivação da lex mercatória, conceito este definido como um aglomerado de normas que comanda comércio internacional baseado nos usos e costumes e boas práticas dos negócios internacionais sem levar em consideração uma ou a lei nacional específica (ALMEIDA, 2004, p.16-17). Outra definição do conceito é que se trata do estabelecimento de normas derivadas do comercio internacional, emanado de um grupo formado pela união das práticas habituais, de modelos padronizados, da jurisprudenciais existentes e das decisões arbitrais, originada através de uma legião de organizações que não possuem vinculo com o Estado, onde seu objeto esta voltado para o fornecimento de serviços aos tribunais de arbitragem internacional (GARCEZ, 1994, p.20).

Em geral a lex mercatoria é utilizada para os julgamentos arbitrais de contratos-tipo, como exemplo os contratos que possuem a cláusula "Knock for Knock", o quais possuem como base fundamental o princípio do pacta sunt servanda, ou seja, a liberdade de contratar.

É importante ressaltar que apesar de lex mercatoria, não possui força de lei perante a doutrina internacional, a mesma pode buscar guarida para o seu reconhecimento no caso de a lex mercatoria ser recebida pela doutrina do Direito Reflexivo (BRANDÃO, 2006, p.245).

O conceito de direito reflexivo se baseia em uma regulação técnica jurídica flexível, originada de debates e negociações na diligência de buscar uma forma de regulação social colocando o Estado em posição de guia e não como diretor da sociedade (ROTH, 1998, p.22), entende se como sociedade os atores envolvidos no mercado em discussão.

A lex mercatoria pode ser vista como uma fotografia atual das práticas do comercio internacional, uma vez que esse se encontra em constante movimento. Ademais do Direito Reflexivo a lex mercatoria apresenta uma característica coercitiva perante aos operadores do comércio internacional. Esta força se dá pela possibilidade de punições indiretas com a exigência de garantias financeiras por participação dos próprios operadores (BRANDÃO, 2006, p.245-246).

Logo, como podemos constatar, a via arbitral é o principal meio jurídico utilizados pelos indivíduos da indústria do petróleo, uma vez que a jurisprudência das cortes arbitrais tem levado em consideração a lex petrolea em conjunto com a lei pactua entre as partes para tomar as suas decisões. Ou seja, além da lei 
pátria acordada os tribunais arbitrais tem levado em consideração as regulações e as melhores praticas do mercado.

Conforme já descrito, o judiciário brasileiro ainda não foi demandado para tal análise. 


\section{CONCLUSÃO}

O entendimento de grande parte da doutrina e da maioria dos operadores do direito sobre regra geral prevista no Código Civil de 2002, é de que o causador do dano tem o dever de reparar integralmente os danos que causou a outrem. Este entendimento está baseado na interpretação da letra do artigo 186 combinado com o artigo 927 do Código Civil.

O presente estudo demonstra que este entendimento está equivocado. Este mal-entendido se dá principalmente pelo fato de que grande parte dos operadores do direito e da doutrina entendem que a cláusula de não indenizar extingue o surgimento da responsabilidade civil, quando o correto pensamento seria de que a cláusula de não indenizar na verdade cessa uma das consequências da responsabilidade civil, que é o dever de indenizar. Logo, tal cláusula não evita a aparição da responsabilidade civil, mas sim limita os seus efeitos.

Assim sendo, o trabalho constatou que a cláusula de não indenizar, embora não prevista expressamente no Código Civil brasileiro, é admitida em nosso ordenamento pátrio, sendo apenas restrita quando percebida na verificação das leis especiais.

O estudo entendeu que a cláusula "Knock for Knock" é uma cláusula de não indenizar, pois um dos seus objetivos é extinguir a indenização previamente pactuada alocando as responsabilidades de acordo com o melhor entendimento acordado pelas partes. Uma vez constatado que a cláusula de não indenizar é permitida no ordenamento brasileiro, partimos para a análise das vedações previstas em leis especiais.

Após análise das vedações foi verificado que a cláusula "Knock for Knock" não se enquadra em nenhum dos impedimentos previstos nas leis especiais, uma vez que não exerce atividade consumerista, não traz prejuízo a ordem pública, não estão inseridas em contratos de adesão e tão pouco admitem o dolo e a culpa grave, bem como não violam a ordem pública ou o princípio da boa-fé.

Logo, uma vez que não existe nenhum impedimento quanto a utilização da cláusula "Knock for Knock", concluímos que a mesma é aceitável no ordenamento pátrio. Este entendimento se baseia na letra dos incisos II e XXXIX do artigo $5^{\circ}$, 
da Constituição Federal de 1988, os quais versam que ninguém será obrigado a fazer ou deixar de fazer alguma coisa senão em virtude de lei e não há crime sem lei anterior que o defina, nem pena sem prévia cominação legal.

O trabalho também expõe o gerenciamento de risco como sendo um dos grandes motivos da utilização da cláusula "Knock for Knock" pela indústria petrolífera, a qual possui a premissa de que não existe melhor indivíduo para controlar o risco do que o próprio dono do processo, obtendo como consequência desta política a redução do risco da atividade e a redução de custos das operações bem como um decréscimo nos valores dos seguros a serem contratados, uma vez que os riscos são melhores identificados por cada parte.

Concluímos também que sem a utilização da cláusula "Knock for Knock", grande parte das atividades praticadas no mercado de óleo e gás com foco nos serviços ligados na exploração e produção de óleo e gás se tornariam inviáveis, impossibilitando a atividade petrolífera como um todo.

Contudo, apesar de verificarmos que a cláusulas "Knock for Knock" deveria ser reconhecida como válida perante ao ordenamento pátrio, a mesma nunca foi demandada pelo judiciário brasileiro, impossibilitando uma análise mais profunda sobre a sua aceitação.

Outro fato que leva a uma desconfiança sobre a sua segurança jurídica, é o fato de que parte do judiciário brasileiro e de seus operadores ainda não possuem o entendimento que uma cláusula de não indenizar seja válida perante ao Código Civil, trazendo assim uma insegurança para a sua utilização.

Porém, como abordado no último capítulo do presente estudo, as cortes arbitrais têm entendido em seus julgamentos que ao analisar as matérias ligadas aos contratos provenientes da indústria petrolífera, os mesmos têm levando em consideração a "lex petrolea" onde a permissibilidade quanto ao uso da cláusula "Knock for Knock" está mais do que consolidada.

Desta forma, o presente estudo recomenda que os contratos originários da indústria óleo e gás que possuam em seu texto a cláusula "Knock for Knock" insiram em seus contratos a cláusula compromissória, não necessitando que as partes escolham outra lei aplicável que não a brasileira, pois como demostrado, além dos árbitros já levarem em consideração a "lex petrolea" em seus vereditos, a cláusula "Knock for Knock", conforme apresentada neste trabalho, é permitida no ordenamento brasileiro. 


\section{REFERÊNCIAS BIBLIOGRÁFICAS}

ALMEIDA, MARIANA LESSA R. DE. Lex petrolea: a Lex Mercatoria dos Contratos Internacionais da Industria do Petróleo. Rio de Janeiro: Monografia de Graduação da Universidade Estadual do Rio de Janeiro, 2004.

ALONSO, PAULO SÉRGIO GOMES. Pressupostos da responsabilidade civil objetiva. São Paulo: Editora Saraiva, 2000.

AMUI; SANDOVAL. Petróleo e Gás Natural para Advogados e Negociadores. Rio de Janeiro: Editora Lumen Juris, 2011.

AVELAR, LETÍCIA MARQUEZ. A cláusula de Não Indenizar. Curitiba: Editora Juruá, 2012.

AZEVEDO, ANTÔNIO JUNQUEIRA. Direito de Exclusividade nas Relações Contratuais de Fornecimento, Função Social do Trabalho e Responsabilidade Aquiliana do Terceiro que Constitui para o Inadimplemento Contratual. In: Revista dos Tribunais, $\mathrm{n}^{\circ}$ 750. São Paulo: Editora Revista dos Tribunais, 1998.

BANDEIRA, LUIZ OTÁVIO DE VILLELA VIANA. As cláusulas de Não Indenizar no Direito Brasileiro. São Paulo: Editora Almedina, 2016.

BRASIL. Lei 8.078 (1990). Código de Defesa do Consumidor. Brasília: Diário Oficial [da] República Federativa do Brasil, 1990.

BRASIL. Lei 9.307 (1996). Lei da Arbitragem. Brasília: Diário Oficial [da] República Federativa do Brasil, 2002.

BRASIL. Lei 10.406 (2002). Código Civil Brasileiro. Brasília: Diário Oficial [da] República Federativa do Brasil, 2002.

BRASIL. Constituição (1988). Constituição da República Federativa do Brasil. Brasília: Senado Federal, 1988.

BRANDÃO, CLARISSE. LEX PETROLEA. Rio de Janeiro: Revista Brasileira de Direito do Petróleo, Gás e Energia n², 2006.

CAVALIERI FILHO, SÉRGIO. Programa de Responsabilidade Civil. São Paulo: Editora Malheiros 2004.

COUTO E SILVA, CLÓVIS V. do. A Obrigação como Processo. Rio de Janeiro: Editora: FGV, 2007

DANTAS, San Tiago, Programa de direito Civil II: Os Contratos. Rio de Janeiro: Editora Rio, 1978

DIAS, JOSÉ DE AGUIAR. Cláusula de Não Indenizar. Rio de Janeiro: Editora Forense, 1980. 
DIAS, JOSÉ DE AGUIAR. Da Responsabilidade Civil. Rio de Janeiro: Editora Lumen Juris, 2012.

DINIZ, MARIA HELENA. Teoria das Obrigações Contratuais e Extracontratuais. Rio de Janeiro: Editora Saraiva, 2008.

DOLINGER, JACOB e TIBURCIO, CARMEN. Arbitragem Comercial Internacional. Rio de Janeiro: Editora Renovar, 2003.

GARCEZ, JOSÉ MARIA ROSSANI. Contratos Internacionais Comerciais. São Paulo: Editora Saraiva, 1994

GOMES, ORLANDO. Obrigações. Rio de Janeiro: Editora Forense, 2006.

MENDONÇA, DIOGO NAVES. Análise Econômica da Responsabilidade Civil. São Paulo: Editora Atlas, 2012.

MONTEIRO, ANTONIO PINTO. Cláusulas Limitativas e de Exclusão de Responsabilidade Civil. Coimbra: Editora Almedina, 2003.

PEREIRA, CAIO MARIO DA SILVA. Instruções de Direito Civil - Volume I. Rio de Janeiro: Editora Forence, 2017.

PEREIRA, CAIO MARIO DA SILVA. Instruções de Direito Civil - Volume II. Rio de Janeiro: Editora Forence, 1972.

PERES, FÁBIO HENRIQUE. Cláusulas Contratuais Excludentes e Limitativas do Dever de Indenizar. São Paulo: Editora Quartier Latin, 2009.

QUINTANS, LUIZ CEZAR P. Manual de Direito do Petróleo. São Paulo: Editora Atlas, 2003.

RODRIGUES, SILVIO. Dos Contratos e das Declaração Unilaterais de Vontade. São Paulo: Editora Saraiva, 2007.

ROTH, ANDRÉ NOEL. Direito em Crise: Fim do Estado Moderno? São Paulo. Editora Malheiros, 1998.

STRENGER, IRINEU. Da autonomia da vontade: direito interno e internacional. São Paulo: Editora LTr, 2000.

TAKACHI, WILLIAM. Comércio Internacional. Aula do curso de Pós Graduação de Direito dos Contratos ministrada na PUC-Rio. Rio de Janeiro - RJ, 2015

TEPEDINO, GUSTAVO; BARBOZA, HELOISA HELENA; MORAES, CELINA BODIN. Código Civil Interpretado Conforme a Constituição da República. V2. Rio de Janeiro; São Paulo e Recife: Editora Renovar, 2006

THOMAS, JOSÉ EDUARDO. Fundamentos de Engenharia de Petróleo. Rio de Janeiro: Editora Interciência, 2001

VENOSA, SILVO DE SALVO. Direito Civil: Responsabilidade civil. São Paulo: Editora Atlas, 2013. 


\section{REFERÊNCIAS DA INTERNET}

AGÊNCIA NACIONAL DO PETRÓLEO, GÁS NATURAL E BIOCOMBUSTÍVEIS Exploração e Producão de Oléo e Gás

Disponível em: http://www.anp.gov.br/wwwanp/exploracao-e-producao-de-oleoe-gas

Acessado em: 01/03/2017

ATLANTIC COUNCIL

O setor de óleo \& gás: um primeiro olhar sobre as mudanças

Disponível em: http://publications.atlanticcouncil.org/brasil-oleo-gas/

Acessado em: 10/01/2017

REVISTA BRASIL ENERGIA

BP, Transocean e Halliburton fecham acordos sobre acidente de Macondo

Disponível em: http://brasilenergiaog.editorabrasilenergia.com/daily/bog-

online/empresas/2015/05/bp-transocean-e-halliburton-fecham-acordos-sobre-

acidente-de-macondo-463725.html

Acessado em: 15/02/2017

REVISTA VEJA

BP derramou 4,9 milhões de barris de petróleo

Disponível em: http://veja.abril.com.br/mundo/bp-derramou-49-milhoes-de-barris-

de-petroleo/

Acessado em: 15/02/2017

CONSELHO DA JUSTIÇA FEDERALL

Enunciado 167

Disponível em: http://www.cjf.jus.br/enunciados/enunciado/300

Acessado em: 10/12/2016

CONSELHO DA JUSTIÇA FEDERALL

Enunciado 169

Disponível em: http://www.cjf.jus.br/enunciados/enunciado/300

Acessado em: 10/12/2016

CONSELHO DA JUSTIÇA FEDERALL

Enunciado 171

Disponível em: http://www.cjf.jus.br/enunciados/enunciado/300

Acessado em: 10/12/2016

INSTITUTO BRASILEIRO DE PETRÓLEO, GÁS E BIOCOMBUSTÍVEIS

Perspectiva de investimento na indústria brasileira (2016-2019)

Disponível em: http://www.ibp.org.br/observatorio-do-setor/perspectiva-deinvestimento-na-industria-brasileira-2016-2019/

Acessado em: 20/12/2016 
PALÁCIO DO PLANALTO

Decretos_Leis de 1937 a 1946

Disponível em: http://planalto.gov.br/ccivil 03/decreto-lei/1937-1946/Del0538.htm

Acessado em: 15/01/2017

PALÁCIO DO PLANALTO

Leis Ordinárias Anteriores a 1960

Disponível em: http://planalto.gov.br/ccivil 03/LEIS/QUADRO/anterior 1960.htm

Acessado em: 15/01/2017

PALÁCIO DO PLANALTO

Leis Ordinárias de 1997

Disponível em: http://planalto.gov.br/ccivil 03/LEIS/QUADRO/1997.htm

Acessado em: 15/01/2017

PALÁCIO DO PLANALTO

Leis Ordinárias de 2010

Disponível em: http://planalto.gov.br/ccivil 03/ Ato2007-

2010/2010/Lei/ Leis2010.htm

Acessado em: 15/01/2017

INCE\&CO

Knock-for-knock liability in the offshore wind farm sector: why is it important, and what issues do you need to be aware of?

Disponível em: http://www.incelaw.com/en/knowledge-bank/publications/knockfor-knock-liability-in-the-offshore-wind-farm-sector-why-is-it-important-and-

what-issues-do-you-need-to-be-aware-of

Acessado em: 20/02/2017

SENADO FEDERAL

Atividade Legislativa

Disponível em:

http://legis.senado.gov.br/legislacao/ListaTextolntegral.action?id=64278\&norma= $\underline{80183}$

Acessado em: 03/03/2017

SUPERIOR TRIBUNAL FEDERAL

Súmulas de 100 a 200

Disponível em:

http://www.stf.jus.br/portal/cms/verTexto.asp?servico=jurisprudenciaSumul a\&pagina=sumula 101200

Acessado em: 03/03/2017

SUPERIOR TRIBUNAL FEDERAL

Súmulas de $\mathbf{3 0 0}$ a $\mathbf{4 0 0}$

Disponível em:

http://www.stf.jus.br/portal/cms/verTexto.asp?servico=jurisprudenciaSumul a\&pagina=sumula 301400

Acessado em: 03/03/2017 
SUPERIOR TRIBUNAL DE JUSTIÇA

Jurisprudência do STJ

Disponível em:

http://www.stj.jus.br/SCON/sumulas/toc.jsp?processo=485\&\&b=SUMU\&th esaurus=JURIDICO\&p=true

Acessado em: 28/01/2017 